\title{
Prediction of open market share repurchases and portfolio returns: evidence from France, Germany and the UK
}

\author{
Dimitris Andriosopoulos $^{1^{*}}$, Chrysovalantis Gaganis ${ }^{2}$, Fotios Pasiouras ${ }^{3,4}$ \\ ${ }^{1}$ Department of Accounting and Finance, University of Strathclyde, United Kingdom \\ ${ }^{2}$ Department of Economics, University of Crete, Greece \\ ${ }^{3}$ Surrey Business School, University of Surrey, UK \\ ${ }^{4}$ Financial Engineering Laboratory, Technical University of Crete, Greece
}

\section{Published in the Review of Quantitative Finance and Accounting}

\begin{abstract}
This study uses logistic regression for the development of prediction models that distinguish between share-repurchasing and non-share repurchasing firms. The estimated models form the basis for an investment strategy, according to which one invests on the stock of the firms that are predicted as repurchasing ones. Using a sample of firms from the UK, France, and Germany, the results show that this strategy generates positive and statistically significant abnormal returns over different investment periods that range between 1 and 18 months.
\end{abstract}

Keywords: abnormal returns, portfolio, prediction, share repurchases

JEL classification: G11, G17, G32

*Corresponding author: (D. Andriosopoulos), Tel.: +44 (0) 141548 3892, E-mail: D.Andriosopoulos@strathclyde.ac.uk; Department of Accounting and Finance, University of Strathclyde, 100 Cathedral Street, Glasgow. G4 0LN, United Kingdom 


\section{Introduction}

Since the 1990's, open market share repurchases have been quite popular among corporate managers. For example, Grullon and Michaely (2002) indicate that expenditures on share repurchase programs increased from $4.8 \%$ in 1980 to $41.8 \%$ in 2000 (relative to total earnings), while more recent data from Standard and Poor's, reveal that share repurchases among S\&P 500 companies reached a record $\$ 172$ billion during the third quarter of 2007. v.Eije and Megginson (2008) find a significant increase in share repurchase activity in the European Union from a low of $3 \%$ of total payouts ( $1 \mathrm{bn}$ ) in 1992 to a high of $34 \%$ (58bn) of total payouts and $50 \%$ relative to real cash dividends. Therefore, it is not surprising that a number of studies have examined among others the determinants and motives of share repurchases (e.g. Grullon and Michaely 2002; Baker et al. 2003; Andriosopoulos and Hoque 2013), and the short- and long-run valuation effects (e.g. Ikenberry et al. 1995; McNally and Smith 2007).

It is widely documented in the literature that share repurchase announcements are followed by significant excess market increases at the time of announcement (Vermaelen 1981; Ikenberry at al. 1995, 2000; Peyer and Vermaelen 2009; McNally and Smith 2007) which tend to persist in the long-run, hence offering economic sources of gain to long-term shareholders (Ikenberry and Vermaelen 1996; Chan et al. 2004). Since open market share repurchases are not firm commitments, they are essentially options that managers can use when they believe the firm's share price is undervalued. When firms repurchase shares in the open market without announcing earlier their intention to do so, managers apply an "early-adoption" strategy and use their inside information to repurchase shares before the undervaluation is discovered by the market (Ikenberry and Vermaelen 1996). In contrast, when firms announce 
their intention to repurchase shares prior to any buyback trades, managers still reserve the option to exploit any stock undervaluation but lose the advantage of exploiting a significant mispricing as the market has already been alerted at the time of the announcement. This "wait-to-adopt" strategy has a smaller advantage against the market in exploiting significant undervaluations and is inferior to the "early-adoption" strategy (Ikenberry and Vermaelen 1996).

Therefore, we investigate whether it is possible to predict those firms that are likely to make a share repurchase announcement and apply an investment strategy based on the forecasted firms, hence simulating the managers' "adoption strategy" whereby we can potentially exploit significant stock mispricings. ${ }^{1}$ Andriosopoulos et al. (2012) strive to develop a model for the classification of firms as repurchasing and non-repurchasing ones. However, they do not examine whether such a model can form the basis for an investment strategy. ${ }^{2}$ As mentioned in Powell (2001) predictability does not imply that abnormal returns can be earned since the market may beat the prediction model, with predictability and zero abnormal returns being perfectly consistent. Therefore, the purpose of the present study is to empirically test and establish whether it is feasible to "beat the market" by investing in the firms predicted as those being more likely to make a share repurchase announcement. In other words, in this research paper we examine whether the identification of firms that are likely to announce an open market share repurchase, and the subsequent

\footnotetext{
${ }^{1}$ Our study is not the first to investigate whether abnormal returns can be earned from the prediction of important corporate events. Katz et al. (1985) examine the usefulness of bankruptcy prediction models in investment strategies, while other recent studies focus on the prediction of takeovers (e.g. Powell 2001; Ouzounis et al. 2009). However, a model specifically designed for open market share repurchases is necessary for at least two reasons. First, the results of the bankruptcy and takeover studies are mixed. Second, there are important differences between those corporate events, leading to differences in the models' predictive ability and the market reaction to such announcements and events. ${ }^{2}$ Another drawback of the study by Andriosopoulos et al. (2012) is that cross-validation resampling technique that they use, does not allow them to examine the out-of-time performance of their model. However, testing the model simultaneously out of sample and out of time is crucial when one aims to use it in the context of an investment strategy.
} 
construction of portfolios that include the stock of these firms, could form the basis for a profitable investment strategy.

We follow a two-step analysis. First, we use logistic regression to develop a classification prediction model that distinguishes between share-repurchasing and non-share repurchasing firms. Then, we form portfolios and examine whether they can beat the market. The results of the first stage could be of particular use to managers in two ways. First, it enables managers to predict the actions of peer firms. Second, it helps managers to identify those firms that are more likely to mimic their corporate decisions and announcements such as in our case, open market share repurchase announcements. The results of the second stage would be of interest to portfolio managers and investors.

For the first step of our analysis, our estimation sample consists of $465 \mathrm{UK}$, French, and German firms that announced a share repurchase between 1997 and 2005, matched by country and year with a control sample of non-repurchasing firms. The holdout sample includes 91 repurchasing firms and 2,285 non-repurchasing ones, operating in the three countries during 2006. We build three country-specific prediction models (i.e. one for each country), and a general one (i.e. using pooled data). Our results show that the prediction ability of the models in the holdout sample ranges between $66.3 \%$ (Germany) and $81.55 \%$ (UK).

For the second step of our analysis, as recommended by Barber and Lyon (1997) and Kothari and Warner (1997), and consistent with Powell (2001) and Ouzounis et al. (2009), we calculate buy-and-hold abnormal returns. The portfolios are formed on January 2, 2006 and we examine their performance over alternative investment horizons (i.e. 1 to 18 months). We find that on aggregate, the UK portfolio shows a moderate abnormal performance of $1.28 \%$ for the first three months, whereas the 
portfolios comprised of French and German firms show a significantly higher performance $(8.84 \%$ and $4.12 \%$ respectively) over the same time frame. Moreover, the average performance of the pooled portfolios remains positive and significant (8.63\%) across the 18-month holding period. Finally, when classifying our buy-andhold portfolios relative to size and market-to-book ratios we find that the portfolios comprised of smaller firms and lower market-to-book ratios have significantly high abnormal returns across the 18-month holding period of $8.54 \%$ and $18.99 \%$ respectively.

Finally, we assess whether the efficient market hypothesis has an impact on the performance of our portfolios by employing the Fama and MacBeth (1973) methodology. The results show that the average idiosyncratic risk of the post-ranking portfolios has some explanatory power on the portfolio returns. In addition, we find that firm-specific characteristics, that are well established in the literature, such as the payment of dividends, firm size and excess cash have a strong and consistent explanatory ability on the performance of the portfolios comprised of firms classified as repurchasing firms by our models.

Overall, the results show that based on the firms predicted to make share repurchase announcement, hence signaling their potential undervaluation, it is possible to devise a successful and profitable portfolio strategy. Moreover, the results on the country-specific portfolios show that the excess returns differ significantly across countries. This is due to the fact that three countries differ significantly in terms countries in terms of institutional settings, taxation of dividends and capital gains (Alzahrani and Lasfer 2012; and v.Eije and Megginson 2008), and regulatory and corporate governance frameworks, such as law enforcement levels, shareholder ownership, and shareholder protection (La Porta et al. 1997, 1999; and Morck et al. 
2005) that lead to different information asymmetries and shareholder behavior towards market signals such as open market share repurchase announcements

The rest of the paper is as follows. Section two provides a background discussion of the abnormal returns literature that is associated with share repurchase programmes. Section three presents the data and the methodological framework. Section four discusses the results, and Section five concludes.

\section{Background discussion on share repurchases and abnormal returns}

Ikenberry at al. (1995) find in the U.S. that repurchasing firms outperform the market by an average of approximately $12 \%$ over a four year period following the announcement of an open market share repurchase programme. For high book-tomarket firms however, they find a significant underreaction of approximately $45 \%$. Similarly, Peyer and Vermaelen (2009) find a significant cumulative average abnormal return of $24.25 \%$ for the 48 months following an open market share repurchase announcement. In Canada, McNally and Smith (2007) report a cumulative abnormal return of approximately $11.7 \%$ for the 36 months following the share repurchase announcement, whereas Ikenberry at al. (2000) report a cumulative abnormal return of $21.4 \%$ for the 36 months after the share repurchase announcement, roughly a monthly average abnormal return of $0.6 \%$.

However, there are significant institutional and regulatory differences between the U.S. and the European markets. This leads to different ownership structures (Morck et al. 2005) and consequently different agency costs and respective managerial motives for announcing an open market share repurchase. Furthermore, there exist significant differences on the levels of information asymmetries, legislative regime and respective investor protection, and corporate culture even between 
different European countries (Bartram et al. 2009; La Porta et al. 1997, 1998, 1999, 2000 , 2002), which lead to different levels of market reaction on the announcement of intention to repurchase shares in the open market (Andriosopoulos and Lasfer 2014; Manconi et al. 2013). Therefore, the effects of share repurchases could vary significantly across countries and consequently managers will have different managerial attitudes towards shareholder value maximisation.

For instance, in France firms tend to be family owned, and in Germany firms tend to be more closely held (Morck et al. 2005) compared to the typically more widely held U.K. firm. Therefore, open market share repurchases would be most likely treated unreceptively. In contrast, in common law countries like the U.K. and the U.S., share repurchases should be more popular since managers are primarily concerned with maximising shareholder value (Brounen et al. 2004) and share repurchase can be used to achieve this purpose (Ikenberry and Vermaelen 1996) while reducing potential agency costs. This is in line with Brounen et al. (2004), where they find that German and French companies are less interested in maximising shareholder value compared to U.K. firms. Therefore, we expect to find a higher postannouncement performance in the U.K. compared to France and Germany, due to the higher information asymmetries.

Furthermore, the respective long-term performance of firms announcing their intention to repurchase shares in the open market could also vary significantly from the long-term performance reported in Canada and the U.S. However, the long-term performance of firms announcing their intention to repurchase their shares in Europe has been scarcely addressed in the literature. Lasfer (2005) reports a cumulative abnormal return of approximately $3 \%$ for the UK for the time period of $[+3$ to +151$]$ days following the share repurchase announcement. However, Rau and Vermaelen 
(2002) find no evidence in the U.K. that firms which make open market share repurchase announcements earn significant positive long-horizon abnormal returns. Nevertheless, Oswald and Young (2004) revisit the Rau and Vermaelen (2002) study and replicate their estimations by employing, for the same date range two samples, one from the Securities Data Corporation (SDC) (as in Rau and Vermaelen 2002), and a second sample collected from a number of sources such as the London Stock Exchange Regulatory News Service and The Financial Times. When analyzing the long-term performance however, they find that both samples experience positive abnormal returns for the one year period following the repurchase announcement.

Lakonishok and Vermaelen (1990) investigate whether it can be a profitable investment strategy to invest around the announcement of a fixed-price tender offer repurchase programme. They find that it is possible to gain an abnormal return of approximately $9 \%$ during the period of the announcement and approximately $23 \%$ for the 24 months following the announcement. Nevertheless, tender-offers vary from open market share repurchases in the main follow ways. First, tender offers are firm commitments as opposed to open market repurchases. Second, in the time frame in which the two repurchase methods are executed and completed ${ }^{3}$. Third, in the premium which firms pay the shareholders for tendering their shares in a short period of time (Masulis 1980; and Comment and Jarrell 1991; report a premium of $16 \%$ whereas Peyer and Vermaelen 2005; report a premium of $7 \%$ for tender offers) as

\footnotetext{
${ }^{3}$ Stephens and Weisbach (1998) investigate the implementation of open market share repurchase programs in the U.S. market and find that firms repurchase either a substantial fraction of the announced shares or almost none at all. Bhattacharya and Dittmar (2003) argue that firms make the announcement but not repurchase because the firm has already attracted the wanted scrutiny from the market. This is supported by Chan et al. 2007, who find that firms repurchasing their shares during the first year of the year of the repurchase announcement, experience lower abnormal returns compared to firms that do not repurchase their shares. Hence arguing that firms do not repurchase their shares because the market has reacted quickly to the signal and therefore the firm cannot take advantage of an undervalued price.
} 
opposed to open market share repurchases which take place at the current market prices.

However, this research study focuses on the open market share repurchases and the abnormal returns that can be gained following the announcement of intention to repurchase shares, an area that has not been thoroughly investigated. Subsequently, we formulate the following two hypotheses. First, we hypothesise that by employing a simple method that does not require a sophisticated analysis and has a low risk it is possible to develop a buy-and-hold strategy of portfolios consisting of firms that have made an open market share repurchase announcement and gain positive postannouncement abnormal returns. Second, we hypothesise that by successfully predicting which firms are more likely to announce an open market share repurchase and trade these shares at the beginning of the year of the forecasted announcement will constitute a profitable investment strategy.

\section{Data and Methodology}

3.1. Data

To build our sample, we first identify all the announcements of intention to repurchase ordinary shares in the open market of France, Germany and the UK, using news articles posted in Perfect Analysis and Factiva databases from $1^{\text {st }}$ January 1997 until $31^{\text {st }}$ December $2006 .{ }^{4}$ Then, information on the share prices and accounting data were obtained from DataStream and Worldscope. Once we exclude firms with missing data, we obtain a sample of 556 repurchasing firms.

\footnotetext{
${ }^{4}$ The study focuses on this period because it was not until 1998 that share repurchasing was allowed to take place more freely in both Germany and France. The Perfect Analysis and Factiva databases report any news announcements that were available in the press made by UK and European firms. Only firms that announced their intention to repurchase ordinary shares were included in the sample. The list of repurchasing firms that formed our starting basis was initially used in the study of Andriosopoulos and Hoque (2013).
} 
To obtain more precise parameter estimates, we use a state-based estimation sample. Each repurchasing firm with available data is matched by country and year with a domestic non-repurchasing firm that did not announce a share repurchase announcement between 1997 and 2005. Consequently, the three country-specific logistic regression models are estimated using 380 firm (UK), 292 firms (France), and 258 firms (Germany), whereas the general model is estimated using the pooled sample of 930 firms. Following the arguments of Palepu (1986) all firms listed on the corresponding stock exchanges as at the 2nd of January 2006 are considered for inclusion in the holdout sample. Once, we exclude firms with missing data, we obtain a sample of 91 repurchasing firms and 2,285 non-repurchasing ones. A breakdown of this sample by country is given in Table 1 , Panel A.

[Insert Table 1 around here]

\subsection{Methodology}

\subsubsection{Logistic regression model}

We employ a standard logit model methodology in order to identify the firm-specific characteristics with discriminatory ability. The variables that are employed in our estimations are selected based on the prevailing hypotheses that underlie share repurchases and are commonly used in the existing literature. In the discussion that follows we briefly outline those variables and the rationale for their inclusion in the present study. The correlation coefficients are provided in Table 1, Panel B. The descriptive statistics are shown in Table 2.

[Insert Table 2 around here]

Firms may decide to distribute their excess cash back to their shareholders via cash dividends or share repurchases in the open market. However, open market share repurchases can be considerably more flexible as a payout method compared to 
dividends, and existing evidence suggests that firms are more likely to repurchase their stock when they have high cash flows and low investment opportunities (Dittmar 2000; Mitchell and Dharmawan 2007). As in Dittmar (2000), to proxy for excess cash we use the ratio of net operating income before taxes and depreciation to total assets at the year-end prior to the repurchase announcement (Cash Flow).

For capturing both a firm's growth opportunities and excess cash flow, we follow Opler and Titman (1993) and construct a dummy variable that takes the value of one for firms that have simultaneously low Tobin's $q$ (lower than the median $q$ of a firm's respective industry for each respective year) and high cash flow (higher than the median cash flow of the respective industry for each year) and the value of zero otherwise (FCF Dummy).

Chen and Wang (2012) argue that firms that repurchase more shares following their announcement to do so will be more likely to have lower cash balances and increased leverage, resulting to financial constraints and liquidity issues. Therefore, repurchasing firms with financial constraints should have lower stock performance following repurchases. In order to control for the impact of financial constraint on firms' decision to make a share repurchase, we use the Kaplan and Zingales (1997) index (financial constraint), which is estimated as in Chen and Wang (2012)

For investigating the impact of undervaluation on the likelihood to announce an open market share repurchase, we follow Ikenberry et al. (1995), Ikenberry et al. (2000), Barth and Kasznik (1999), and Dittmar (2000), and we include as a proxy for potential undervaluation the market-to-book ratio at the year-end prior to share repurchase announcement $(M K B K)$. Alternatively, in the spirit of Peyer and Vermaelen (2009) and Andriosopoulos and Hoque (2013) we control for potential undervaluation by employing the pre-repurchase share price returns for a number of 
time intervals. In particular, we use the 6-month (days -151 to 2 days) market adjusted stock returns. ${ }^{5}$ Gong et al (2008) argue that managers undertaking share repurchases for reasons other than signaling their firms' mispricing, have the incentive to deflate their firm's share price prior to a share repurchase. This can be achieved by managing the pre-repurchase reported earnings, which could lower the share price prior to the share repurchases resulting to buying the share at a bargain price. Gong et al (2008) find evidence suggesting that abnormal accruals, used as a proxy for earnings management, are significantly associated with actual share repurchases. Therefore, we control for the impact of pre-repurchase announcement earnings management on the likelihood of a firm's decision to make a share repurchase announcement. We include the variable abnormal accruals estimated as in Gong et al. (2008).

The decision to distribute excess capital as a payout to shareholders through a share repurchase reduces a firm's equity capital, which in turn increases its leverage ratio. Consequently, Bagwell and Shoven (1988) and Hovakimian et al. (2001) argue that a share repurchase programme, displays the managers' preference to employ debt instead of equity, so that they can approach their target leverage ratio. Indeed, a number of empirical studies report evidence that firms with low leverage are more likely to repurchase their shares (Hovakimian et al. 2001; Mitchell and Dharmawan 2007; Dittmar 2000). Therefore, to proxy for leverage we use the ratio of total debt to total assets at the year-end prior to the repurchase announcement (Leverage).

Vermaelen (1981) argues that smaller firms are more likely to have higher information asymmetries, since they get less scrutinised by analysts and the media. Consequently, smaller firms are more likely to be misvalued, which leads to a greater

\footnotetext{
${ }^{5}$ We replicate our estimations by using alternatively the market-adjusted returns during the one-year period prior to the announcement (days -261 to -2 ) and the smaller timeframes -42 to -2 days (2 months), and -22 to -2 days ( 20 days) prior to the announcement of intention to repurchase. In all cases, the results remain the same.
} 
likelihood of repurchasing their shares. In line with this argument, are the findings of Mitchell and Dharmawan (2007) who find that firms which are small and announce their intention to repurchase a large fraction of their outstanding capital, have a significant signalling impact. In addition, Dittmar (2000), Grullon and Michaely (2002), and Ikenberry et al. (1995) report evidence that size has a positive relationship with the volume of share repurchases. Hence, size is a firm specific characteristic, which can have a significant impact on the likelihood to announce an open market share repurchase. To capture the impact of size on the repurchasing decision we use the natural logarithm of a firm's total assets at the year-end prior to the share repurchase announcement (Size).

Typically, capital gains tax rate is lower than the respective personal income tax rate. Therefore, share repurchases can have a significant advantage over cash dividends, from a tax perspective. Within this context, the personal tax savings hypothesis, states that share repurchases can be more tax efficient and more beneficial to shareholders, compared to cash dividends (Grullon and Michaely 2002). While Bagwell and Shoven (1989) and Dittmar (2000) find no evidence of taxation having a significant impact on corporate payouts, a number of research studies do find evidence of tax having a significant influence on firms' decision making on payouts, and of the market having a favorable reaction due to the tax impact (Masulis 1980; Grullon and Michaely 2002). Furthermore, open market share repurchases can have advantages relative to cash dividends such as tax differential and that they do not pose a commitment to the firm. Therefore, open market share repurchases can be considered to be substitutes to cash dividends (Grullon and Michaely 2002). Consequently, we assume that a firm's payment of dividends can have a significant discriminatory ability that will help determine a firm's propensity to announce an 
open market share repurchase. We follow Dittmar (2000) and Jagannathan and Stephens (2003), and we employ the proxy variable Dividend Payout, which is defined as the ratio of total regular cash dividends relative to net income. Additionally, for incorporating the tax impact in our models, we follow McNally (1999) and we proxy for the average tax rate with the proxy variable Dividend Yield, which is the dividend yield ratio.

Finally, for capturing the effect that a firm's profitability and operating performance has on the likelihood to announce and open market share repurchase, we follow Grullon and Michaely (2004) and we use the ratio of net income to total assets $(R O A)$. We expect to find that the higher the profitability the more available resources a firm will have and consequently more likely to announce an open market share repurchase for distributing the excess cash back to its shareholders. Consequently, a higher profitability will lead to a higher market reaction on the buyback announcement and a more positive share price performance following the announcement due to the market's anticipation of a sustainable high profitability

\subsubsection{Portfolios construction}

The logistic regression model described in the previous section is estimated using data over the period 1997-2005. Then, the estimated parameters are used to test the forecasting ability of the model in 2006. To account for potential country-level effects, and test the robustness across alternative approaches, we develop three country-specific prediction models (i.e. one for each country), and a general one (i.e. using pooled data). In each case, the shares of all the firms that the model identifies as share-repurchasing ones (correctly or not) are included in the corresponding portfolio. 
Thus, we assume that the portfolios are formed on 1 January 2006, and we examine various investment n-month horizons up to 18 months. ${ }^{6}$

As recommended by Barber and Lyon (1997) and Kothari and Warner (1997), and consistent with Powell (2001) and Ouzounis et al. (2009), we calculate buy-andhold abnormal returns. We estimate the logarithmic return based on the dividend adjusted prices of each stock. Then, to form the basis for the construction of a hypothetical benchmark portfolio we estimate the dividend adjusted logarithmic returns for the respective industry index $j$ of each firm $i$, based on the two-digit Standard Industrial Classification (SIC) code. The difference between the firmspecific and industry-specific returns, provide the market-adjusted return for each firm in our sample.

Following earlier studies the abnormal performance is defined as the crosssectional average of the individual buy-and-hold abnormal stock returns (see e.g. Barber et al. 1999; Powell 2004; Ouzounis et al. 2009). This allows us to adjust the returns for survivorship bias. Thus, the benchmark-adjusted BAHAR for a portfolio $p$ of $N$ firms over a holding of $T$, as follows:

$$
\operatorname{BAHAR}_{p, T}=\frac{1}{N} \sum_{i=1}^{T} \operatorname{BAHAR}_{i, T}
$$

where

$$
\text { BAHAR }_{i, T}=\prod_{t=1}^{T}\left(1+R_{i, T}\right)-\prod_{t=1}^{T}\left(1+R_{c, T}\right)
$$

The monthly performance $\left(\mathrm{R}_{\mathrm{i}, \mathrm{T}}\right.$ and $\left.\mathrm{R}_{\mathrm{c}, \mathrm{T}}\right)$ is computed as the ratio between the month-end value (stock price or index value) and the previous month's respective value (adjusted for dividends). $T$ denotes the number of months of each investment

\footnotetext{
${ }^{6}$ We do not employ longer time-horizons as longer horizons clash with the 2007-09 financial crisis which would contaminate and distort our results.
} 
period within which the returns are compounded monthly. The statistical significance of the portfolio BAHAR is tested using the established t-statistic procedure.

\section{Empirical results}

\subsection{Logistic regressions}

Table 3, Panel A presents the logit model coefficient estimates. For each country as well as for the pooled model, we develop two specifications. The first specification, in Panel A, corresponds to a base model that does not incorporate information about financial constraints, prior returns, and abnormal accruals. These variables are then added in the second specification. ${ }^{7}$

The results show that size appears to have a positive impact on the probability of a repurchase. This is robust across both specifications and for all the countries, as well as in the case of the pooled model. With the exception of the UK, dividend payout is also positive and statistically significant. Other than that we observe that the factors that influence the probability of a repurchase may vary among countries. Furthermore, the three variables that we add in the second specification do not have a robust impact on the probability of a repurchase. More detailed, our abnormal accruals indicator is statistically significant only in the case of the UK, and our proxy for prior returns is statistically significant only in the case of France.

Of particular importance in our setting is whether the model is able to differentiate between repurchasing and non-repurchasing firms. So, we now turn to the classification and prediction ability of the models, presented in Table 3, Panel B. Looking at the training sample, the results are satisfactory with the average

\footnotetext{
${ }^{7}$ We would like to thank an anonymous reviewer for recommending the estimation of the second specification. Due to missing data, the estimation sample for this specification includes 124 UK firms, 84 French firms, and 54 German firms. The corresponding figures for the holdout sample are: 719 (UK), 384 (France), and 349 (Germany).
} 
classification accuracy exceeding $70 \%$ in most of the cases, regardless of the specification.

However, what really matters for a successful investment strategy is the predictive ability of the models in the holdout sample. In the case of Specification 1, the results in the holdout sample confirm the prediction ability of the models, with the average correct classification accuracies ranging between $66.3 \%$ in the case of Germany to $81.55 \%$ in the case of the UK. The model that uses the pooled data also performs well classifying correctly $77.35 \%$ of the firms, on average. Interestingly enough, all the models achieve quite balanced accuracies between the two groups of firms with the Germany-specific model being the best example. More detailed, this model classifies correctly $69 \%$ of the non-repurchasing firms, and $63.60 \%$ of the share repurchasing firms. In the case of Specification 2, the out-of sample performance of the models is considerably worse in all cases, ranging from $56.53 \%$ (France) to $73.45 \%$ (pooled sample). Additionally, the models perform very pool in the case of Group 2 (i.e. repurchasing firms). Since Specification 1 has a significantly better predictive performance compared to Specification 2, as discussed earlier, we continue our analysis based on the classifications of Specification 1.

[Insert Table 3 around here]

\subsection{BAHAR}

Table 4 reports the BAHAR for each one of the four models, estimated with Specification 1, for holding periods of 1 to 18 months. ${ }^{8}$ Panel A reports the portfolio BAHAR results for each country and the pooled sample returns. The pooled sample results show a modest positive abnormal return of approximately $1 \%$ that keeps

\footnotetext{
${ }^{8}$ For brevity we only present the results obtained from Specification 1 . As expected, the results of Specification 2 have very poor performance due to the low specification accuracies in the holdout sample. Both the BAHAR and the Fama and MacBeth results for Specification 2 are available from the authors upon request.
} 
increasing significantly during the following few months reaching approximately a $6 \%$ excess return. Following the six-month holding period the portfolio performance reaches a plateau of approximately $4 \%$ up to the 12 -month holding period, which then peaks at the 18 months with $8.63 \%$ excess returns. This result suggests that with a simple buy-and-hold strategy based on the predicted stocks, without rebalancing or categorizing the stocks held in the portfolio, yields a consistent positive and significant abnormal performance. This is consistent with the undervaluation hypothesis (Vermaelen, 1981; Ikenberry et al., 1995).

Looking at the country-specific models, we observe that in most cases the proposed strategy generates positive and statistically significant abnormal returns. In particular, the portfolio holding only UK firms displays the lowest return which peaks on the first month at $1.55 \%$, then remains stable at approximately $1 \%$ for the following six months and dissipates after the six-month holding period. Moreover, we find that the performance of the UK portfolio reverses after holding the portfolio for 15 and 18 months with approximately $-1.5 \%$ and $-1.22 \%$ respectively. An explanation for the poor performance of the UK model is the large absolute number of non-share repurchasing shares that are misclassified as share repurchasing ones. More detailed, this model classifies correctly $86.2 \%$ of the non-share repurchasing shares, or in other words, it misclassifies around $13.8 \%$ of the non-share repurchasing shares as repurchasing ones. Given the large number of non-share repurchasing shares in the holdout sample for the UK, this means that 187 non-share repurchasing shares (i.e. $13.8 \%$ of 1,353 ) are misclassified. Thus, a portfolio constructed on the basis of these predictions would include 217 shares from which only 30 shares (i.e. $76.9 \%$ of 39) would belong to firms that actually proceeded to a repurchase. ${ }^{9}$ Consequently, the

\footnotetext{
${ }^{9}$ This portfolio actually includes 213 firms due to missing values in four cases.
} 
losses or small abnormal returns generated by the misclassified firms counterbalance any positive returns generated by the stocks of the correctly classified repurchasing firms. For example, a theoretical portfolio that would include only the UK repurchasing firms could generate abnormal returns between $2.76 \%$ ( 3 months) and $8.82 \%$ (18 months).

In contrast, Germany and especially France, yield significantly higher abnormal returns which remain positive consistently through each holding period up to 18 months. In detail, the portfolio holding French firms yields a range of abnormal returns between $8.84 \%$ ( 3 months) to $31.76 \%$ (18 months). The corresponding figures for Germany are lower than France; however, they remain positive and statistically significant, with values ranging between $4.02 \%$ (3 months) and 8.06\% (15 months).

[Insert Table 4 around here]

In addition, we split our portfolios based on firm growth (proxied by the marketto-book ratio). The results are reported in Table 4 (Panel B) and show that overall the low growth firms generate consistently higher positive abnormal returns. A small exception to this though are the results for Germany where high-growth firms tend to generate higher returns during the shorter holding periods of up to three months, whereas afterwards they become quite volatile and produce significantly negative excess returns of $-2.02 \%$ (12 months) contrary to the low-growth portfolio which generates $9.57 \%$ during the same holding period. Our results on the market-to-book classification are in line with Ikenberry et al. (1995) who find that value stocks (i.e. firms with high market-to-book ratio) significantly outperform growth stocks (i.e. firms with low market-to-book ratio).

Ikenberry et al. (1995) show that small firms enjoy a significantly higher market reaction of approximately $8 \%$ compared to $2 \%$ for large firms, during the time of the 
share buyback announcement. Therefore, we split our portfolios relative to firm size (proxied by total assets). The results reported in Table 4 (Panel C) show that for the pooled sample the small-firms portfolio consistently outperforms the large-firms portfolio for all holding periods up to 9 months, after which the pattern is reversed and large stocks outperform the small stocks in the longer run. This is also in line with Chan et al. (2004) who find that at the time of the announcement smaller firms enjoy a higher market reaction but on the long run (a four year holding period) it is large firms that have a better stock price performance. For the country-specific portfolios, we observe that in France, with the exception of the first month the small-stocks portfolio consistently outperforms the large stocks for all holding periods. In contrast, in the UK it is the large and mature firms that outperform the smaller stocks with the exception of the 1-month holding period. In Germany, the small stocks portfolio outperforms the large stocks for the first six months, after which the trend reverses and it is the large stocks that provide higher returns.

Finally, the results also reveal that even an investment strategy that ignores the country-specific attributes, by developing a common prediction model and a single portfolio, could also generate positive and statistically significant abnormal returns. However, these returns tend to be lower than the ones obtained through the countryspecific models for France and Germany, due to the cross-country regulatory, institutional and tax variations.

\subsection{Fama- MacBeth regressions}

In this section we follow the standard two-stage methodology of Fama and MacBeth (1973) to assess whether the firm-specific characteristics employed for constructing the portfolios can explain the stock performance during the varying holding periods. In the first stage we run a number of time series regressions equal in 
number to the number of firms identified by our model as repurchasing firms. The regressions are estimated as follows:

$$
R_{t}^{i}=\beta_{0}+\beta_{i}^{M} R_{t}^{M}+\epsilon_{t}^{i}
$$

Where $R_{t}^{i}$ is a vector of returns ( $\left.\mathrm{t} \times 1\right), R_{t}^{M}$ is a vector ( $\left.\mathrm{t} \times 1\right)$ of industry returns based on the 2-digit industry classification code, $\beta_{0}$ is the intercept, and $\beta_{i}^{N}$ is the factor loading (beta). For each month $\mathrm{t}$ and each firm identified by our model as repurchasing firm, we use the firms' and respective industry index returns over the 36 months (Jan:2002 - Dec:2004) in order to identify the pre-ranking $\beta_{i}^{N}$. Then firms are ranked each month based on their pre-ranking beta $\beta_{i}^{N}$, into five equally weighted portfolios. The post-ranking factor loadings ${ }^{10}$ (betas) are estimated as follows:

$$
R_{t}^{p}=\gamma_{0}+\gamma_{p}^{M} R_{t}^{M}+\epsilon_{t}^{p}
$$

where, $R_{t}^{p}$ is the equal-weighted return for portfolio $p$ in month $t$ and this regression is run for each of the 12 months (Jan:2005 - Dec:2005) prior to 2006. For the second step, following the estimation of equation 4 , we run the following regression ${ }^{11}$ in order to test the drivers of the stock performance of the formed portfolios as follows:

$$
R_{i, t}=\gamma_{0}+\gamma_{1, t} \beta_{i}+\gamma_{2, t} \beta_{i}^{2}+\gamma_{3, t} s_{i}+\Gamma \text { firm characteristics } \text { fit, }+\eta_{i, t}
$$

where, $R_{i, t}$ is the one-period percentage return on security for each tested time interval $t-1$ to $t$ (Jan:2006 - Jun:2007). $\beta_{i}$ and $\beta_{i}^{2}$ are the market coefficient and the squared market coefficient, respectively, and $s_{i}$ is the standard deviation of the

\footnotetext{
${ }^{10}$ The standard errors are adjusted for heteroskedasticity and autocorrelation based on Newey and West (1987)

${ }^{11}$ We run alternative regressions of including only $\beta_{\mathrm{i}}$, and alternatively only $\beta_{\mathrm{i}}$ and $\beta_{\mathrm{i}}^{2}$ and the results remain qualitatively unaltered.
} 
residual returns $\left(\epsilon_{t}^{p}\right)$ from equation 4 . Firm characteristics is a matrix of lagged firmspecific variables as previously described in section 3.2.1.

Table 5 reports the Fama MacBeth (1973) regression estimations based on the firm specific characteristics employed in specifications 1 and 2 respectively of the logistic regression, as discussed earlier in section 4.1. The results show that in the UK the average variability of standard errors (s) has a positive and significant explanatory power of the portfolio stock returns up to a 6-month holding period. In addition, the results show that ROA has small but negative relationship with the portfolio performance. The results also show that the payment of dividends has largely a negative relationship with the portfolio performance across most holding periods. Finally, in the case of the UK we find a strong and negative relationship between the performance of the portfolio for long-term holding periods and abnormal accruals, consistent with Gong et al. (2008).

In France, we find that dividend and excess free cash flow explains the portfolio performance for most holding periods. This reflects the market's skepticism of the firms' potential for future growth as these firms accumulate more cash resulting to higher agency costs. In addition, the results that size and profitability have a positive and significant relationship with the portfolio performance across most holding periods. Finally, downward earnings management, captured by abnormal accruals, has a negative relationship with the portfolio performance but only for the 9month holding period.

The results in Germany show that both $\beta^{2}$ and s explain the portfolio returns for the first 3 months of holding periods, with $\beta^{2}$ having a positive relationship with portfolio returns up to the 6-month holding period. In addition, the results show that the payment of dividends has a consistent negative relationship with portfolio 
performance largely across all holding periods, while size has a positive relationship for the longer holding periods of 6 to 18 months. The results also show that excess free cash flow has a positive relationship with the portfolio performance from the 3 month to the 18-month holding period. In addition, profitability has a negative relationship for the shorter holding periods but then reverses to a positive relationship for the longer holding periods. Finally, past returns appear to have a strong and positive relationship with the portfolio performance of the shorter 1- and 3-month holding periods.

\section{[Insert Table 5 around here]}

Finally, the results from the portfolios comprised of all three countries show that the average standard deviation of standard errors (s) from the post-ranking portfolio estimations, has a positive and significant impact on the portfolio performance. This suggests that firms in our portfolios that have higher idiosyncratic risk perform better over the short-term holding period. In addition, we find that the payment of dividends and the holding of high levels of excess cash lead to a poor portfolio performance across almost all holding periods of our portfolios. In contrast, size has a positive and significant explanatory power suggesting that firms predicted by our model as repurchasing firms and are larger in size have a better stock market performance. Finally, we find that on the long-run those firms that have a good market performance in the past but have higher earnings management, captured by abnormal accruals, lead to a poor portfolio performance.

\section{Conclusions}

A number of studies document that open market share repurchase announcements are associated with positive abnormal returns in the short- and long-term horizon following the announcement of intention. Despite this fact, there are no studies testing 
whether the ability to predict which firms are more likely to make an open market share buyback announcement, could form the basis for a successful investment strategy. The present study presented a first attempt to close this gap in the literature.

Using a sample of 465 UK, French, and German firms that announced a share repurchase during 1997-2005, and an appropriate control group of non-repurchasing firms, we estimated four logistic regression models to predict the share repurchases. The estimated models were tested in holdout samples that correspond to the true population of repurchasing and non-repurchasing firms in the three countries during 2006. In each case, the shares of all the firms that the models identified as sharerepurchasing ones (correctly or not) were included in the corresponding portfolio.

The average prediction ability of the models in the holdout sample was satisfactory ranging between $66.3 \%$ (Germany) and $81.55 \%$ (UK). The results show that by incorporating a cross-country or an individual-country portfolio it can lead to a successful investment strategy. Moreover, the portfolio performance varies among holding periods but significantly high returns can be gained between a modest $1.5 \%$ for 1-month in the UK and $31.76 \%$ for an 18-month holding period in France. Further, we employ alternative investment strategies by categorizing our portfolios based on size and growth which confirms our findings that statistically significant and positive excess returns can be realized. Finally, we employ a Fama and MacBeth (1973) methodology in order to investigate whether the efficient market hypothesis affects the performance of our portfolios. Overall, the results show that it is the average idiosyncratic risk of the post-ranking portfolios that has some explanatory power of our portfolio returns, while established firm-specific characteristics such as the payment of dividends, firm size, and excess cash have a strong explanatory ability on 
the portfolio performance for those firms predicted as repurchasing firms by our models.

Future research could extend the research presented in this study, in at least two ways. First, by incorporating corporate governance and management-specific attributes in the prediction models. This could potentially improve further the ability of the prediction models, in distinguishing between the two groups of firms. Unfortunately, such data were not available in our case. Second, by using alternative classification techniques, like support vector machines or neural networks. 
Table 1: Composition of Samples and Correlation Matrices

\begin{tabular}{|c|c|c|c|c|c|c|c|c|}
\hline \multirow{2}{*}{$\begin{array}{c}\begin{array}{c}\text { Panel A: Sample } \\
\text { composition }\end{array} \\
\text { Estimation Sample }\end{array}$} & \multicolumn{2}{|c|}{ UK } & \multicolumn{2}{|c|}{ France } & \multicolumn{2}{|c|}{ Germany } & \multicolumn{2}{|c|}{ All countries } \\
\hline & $\begin{array}{l}\text { Non- } \\
\text { repurchasing } \\
\text { firms }\end{array}$ & $\begin{array}{l}\text { Repurchasing } \\
\text { firms }\end{array}$ & $\begin{array}{l}\text { Non- } \\
\text { repurchasing } \\
\text { firms }\end{array}$ & $\begin{array}{l}\text { Repurchasing } \\
\text { firms }\end{array}$ & $\begin{array}{l}\text { Non- } \\
\text { repurchasing } \\
\text { firms }\end{array}$ & $\begin{array}{l}\text { Repurchasing } \\
\text { firms }\end{array}$ & $\begin{array}{l}\text { Non- } \\
\text { repurchasing } \\
\text { firms }\end{array}$ & $\begin{array}{l}\text { Repurchasing } \\
\text { firms }\end{array}$ \\
\hline 1997 & 8 & 8 & 1 & 1 & 0 & 0 & 9 & 9 \\
\hline 1998 & 16 & 16 & 14 & 14 & 0 & 0 & 33 & 33 \\
\hline 1999 & 14 & 14 & 16 & 16 & 8 & 8 & 38 & 38 \\
\hline 2000 & 13 & 13 & 26 & 26 & 18 & 18 & 57 & 57 \\
\hline 2001 & 21 & 21 & 13 & 13 & 30 & 30 & 58 & 58 \\
\hline 2002 & 31 & 31 & 25 & 25 & 23 & 23 & 79 & 79 \\
\hline 203 & 24 & 24 & 22 & 22 & 13 & 13 & 59 & 59 \\
\hline 2004 & 31 & 31 & 20 & 20 & 14 & 14 & 65 & 65 \\
\hline 2005 & 29 & 29 & 9 & 9 & 23 & 23 & 61 & 61 \\
\hline Total Estimation Sample & 190 & 190 & 146 & 146 & 129 & 129 & 465 & 465 \\
\hline Holdout Sample - 2006 & 1,353 & 39 & 452 & 30 & 480 & 22 & 2,285 & 91 \\
\hline
\end{tabular}

\begin{tabular}{|c|c|c|c|c|c|c|c|c|c|c|c|c|}
\hline \multicolumn{13}{|c|}{ Panel B: Correlation Matrix of Independent Variables (Estimation Sample) } \\
\hline & & $\begin{array}{l}\text { Cash } \\
\text { Flow }\end{array}$ & $\begin{array}{c}\text { FCF } \\
\text { Dummy }\end{array}$ & $\begin{array}{c}\text { Dividend } \\
\text { Payout }\end{array}$ & $\begin{array}{l}\text { Dividend } \\
\text { Yield }\end{array}$ & Leverage & MKBK & SIZE & ROA & KZ-index & $\begin{array}{c}\text { Abnormal } \\
\text { accruals }\end{array}$ & $\begin{array}{c}\text { Prior } \\
\text { returns }\end{array}$ \\
\hline \multirow{11}{*}{ 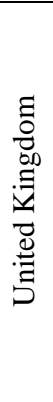 } & Cash Flow & 1.000 & & & & & & & & & & \\
\hline & FCF Dummy & 0.064 & 1.000 & & & & & & & & & \\
\hline & Dividend Payout & 0.043 & 0.071 & 1.000 & & & & & & & & \\
\hline & Dividend Yield & $0.143 * *$ & 0.041 & $0.106 *$ & 1.000 & & & & & & & \\
\hline & Leverage & $-0.359 * *$ & -0.016 & 0.035 & 0.027 & 1.000 & & & & & & \\
\hline & MKBK & 0.004 & 0.031 & $-0.117 *$ & 0.001 & -0.064 & 1.000 & & & & & \\
\hline & SIZE & $0.292 * *$ & $0.162 * *$ & $0.307 * *$ & $0.250 * *$ & $0.156^{* *}$ & -0.031 & 1.000 & & & & \\
\hline & ROA & $0.624 * *$ & 0.044 & 0.058 & $0.204 * *$ & $-0.487 * *$ & 0.035 & $0.301 * *$ & 1.000 & & & \\
\hline & $\mathrm{KZ}$ index & -0.042 & 0.010 & 0.003 & -0.001 & -0.063 & -0.121 & -0.054 & -0.081 & 1.000 & & \\
\hline & Abnormal accruals & $0.427 * *$ & -0.026 & 0.058 & 0.004 & -0.027 & -0.013 & 0.014 & 0.098 & -0.037 & 1.000 & \\
\hline & Prior returns & -0.038 & $-.202^{*}$ & -0.014 & -0.047 & 0.079 & $-.352 * *$ & 0.049 & 0.013 & 0.094 & 0.009 & 1.000 \\
\hline
\end{tabular}




\begin{tabular}{|c|c|c|c|c|c|c|c|c|c|c|c|c|}
\hline \multirow{11}{*}{ 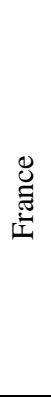 } & Cash Flow & 1.000 & & & & & & & & & & \\
\hline & FCF Dummy & 0.045 & 1.000 & & & & & & & & & \\
\hline & Dividend Payout & -0.030 & $0.165^{* *}$ & 1.000 & & & & & & & & \\
\hline & Dividend Yield & 0.069 & -0.014 & 0.110 & 1.000 & & & & & & & \\
\hline & Leverage & -0.101 & 0.004 & -0.048 & -0.053 & 1.000 & & & & & & \\
\hline & MKBK & $-0.348 * *$ & -0.065 & -0.023 & -0.047 & -0.040 & 1.000 & & & & & \\
\hline & SIZE & 0.063 & $0.286 * *$ & $0.399 * *$ & 0.041 & $0.159 * *$ & -0.077 & 1.000 & & & & \\
\hline & ROA & 0.039 & 0.052 & 0.072 & $0.217 * *$ & -0.090 & -0.016 & 0.100 & 1.000 & & & \\
\hline & $\mathrm{KZ}$ index & -0.211 & -0.022 & $0.176 * *$ & -0.119 & $0.463 * *$ & $0.372 * *$ & 0.209 & -0.114 & 1.000 & & \\
\hline & Abnormal accruals & -0.149 & -0.008 & 0.167 & -0.029 & 0.087 & 0.078 & $0.308 * *$ & 0.006 & 0.100 & 1.000 & \\
\hline & Prior returns & $-0.220 *$ & -0.143 & 0.018 & -0.174 & 0.164 & 0.173 & -0.056 & -0.177 & $0.328 * *$ & -0.049 & 1.000 \\
\hline \multirow{11}{*}{ 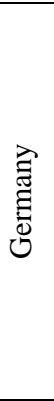 } & Cash Flow & 1.000 & & & & & & & & & & \\
\hline & FCF Dummy & $0.179 * *$ & 1.000 & & & & & & & & & \\
\hline & Dividend Payout & $0.141 *$ & 0.002 & 1.000 & & & & & & & & \\
\hline & Dividend Yield & -0.008 & 0.069 & $0.201 * *$ & 1.000 & & & & & & & \\
\hline & Leverage & -0.001 & $0.176^{* *}$ & 0.035 & -0.002 & 1.000 & & & & & & \\
\hline & MKBK & 0.069 & $-0.266^{* *}$ & 0.094 & 0.065 & -0.087 & 1.000 & & & & & \\
\hline & SIZE & $0.311 * *$ & $0.350 * *$ & $0.167 * *$ & $0.162 * *$ & 0.088 & -0.063 & 1.000 & & & & \\
\hline & ROA & 0.039 & -0.067 & 0.092 & $0.376^{* *}$ & -0.076 & 0.046 & 0.112 & 1.000 & & & \\
\hline & $\mathrm{KZ}$ index & $-.407 * *$ & 0.110 & -0.004 & -0.213 & $0.529 * *$ & -0.12 & 0.142 & -0.034 & 1.000 & & \\
\hline & Abnormal accruals & 0.028 & -0.095 & -0.069 & -0.025 & -0.207 & $-0.477 * *$ & 0.091 & 0.068 & -0.024 & 1.000 & \\
\hline & Prior returns & -0.071 & -0.044 & -0.074 & -0.176 & 0.114 & -0.034 & 0.110 & 0.186 & 0.070 & -0.101 & 1.000 \\
\hline \multirow{11}{*}{ 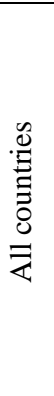 } & Cash Flow & 1.000 & & & & & & & & & & \\
\hline & FCF Dummy & 0.053 & 1.000 & & & & & & & & & \\
\hline & Dividend Payout & 0.023 & $0.090 * *$ & 1.000 & & & & & & & & \\
\hline & Dividend Yield & $0.089 * *$ & 0.025 & $0.069 *$ & 1.000 & & & & & & & \\
\hline & Leverage & $-0.296 * *$ & 0.024 & 0.011 & 0.020 & 1.000 & & & & & & \\
\hline & MKBK & -0.028 & -0.027 & -0.026 & -0.027 & -0.047 & 1.000 & & & & & \\
\hline & SIZE & $0.217 * *$ & $0.241 * *$ & $0.286 * *$ & $0.180 * *$ & $0.146^{* *}$ & -0.049 & 1.000 & & & & \\
\hline & ROA & $0.599 * *$ & 0.029 & 0.046 & $0.172 * *$ & $-0.396 * *$ & 0.024 & $0.222 * *$ & 1.000 & & & \\
\hline & $\mathrm{KZ}$ index & -0.040 & 0.020 & 0.077 & -0.078 & $0.124 *$ & -0.098 & 0.032 & -0.063 & 1.000 & & \\
\hline & Abnormal accruals & $0.220^{* *}$ & -0.039 & 0.090 & 0.032 & -0.033 & -0.018 & 0.101 & 0.047 & -0.019 & 1.000 & \\
\hline & Prior returns & -0.025 & $-0.141 *$ & 0.008 & $-0.138^{*}$ & 0.119 & $-0.256 * *$ & 0.049 & 0 & $0.136^{*}$ & -0.035 & 1.000 \\
\hline
\end{tabular}

Note: This table reports sample-based basic statistics. Panel A report the annual sample composition for each country, between repurchasing and non-repurchasing firms. Panel B reports the correlation matrix of the independent variables used in this study. The variables are defined in Appendix $1 . * * *, * *$, and $*$ indicate

statistical significance at the 1,5 , and $10 \%$ level, respectively. 
Table 2: Descriptive statistics of the estimation sample

\begin{tabular}{|c|c|c|c|c|c|}
\hline \multirow[b]{2}{*}{ United Kingdom } & \multicolumn{2}{|c|}{ Non-repurchasing firms } & \multicolumn{2}{|c|}{ Repurchasing firms } & \multirow[b]{2}{*}{$\begin{array}{c}\text { Kruskal } \\
\text {-Wallis } \\
\text { (p-values) }\end{array}$} \\
\hline & Mean & $\begin{array}{l}\text { Standard } \\
\text { Deviation }\end{array}$ & Mean & $\begin{array}{l}\text { Standard } \\
\text { Deviation }\end{array}$ & \\
\hline Cash Flow & -0.158 & 1.340 & 0.111 & 0.105 & $0.000 * *$ \\
\hline FCF Dummy & 0.195 & 0.397 & 0.363 & 0.482 & $0.000 * *$ \\
\hline Dividend Payout & 0.448 & 1.886 & 1.817 & 4.500 & 0.314 \\
\hline Dividend Yield & 2.043 & 2.338 & 3.315 & 2.798 & $0.000 * *$ \\
\hline Leverage & 0.201 & 0.343 & 0.225 & 0.178 & $0.003 * *$ \\
\hline MKBK & 2.473 & 8.503 & 1.124 & 18.073 & 0.493 \\
\hline SIZE & 11.271 & 2.524 & 14.092 & 2.531 & $0.000 * *$ \\
\hline ROA & -0.128 & 0.677 & 0.034 & 0.159 & $0.000 * *$ \\
\hline KZ-index & -0.159 & 2.056 & -0.188 & 3.354 & $0.025^{* *}$ \\
\hline Abnormal accruals & -0.045 & 0.035 & -0.044 & 0.014 & $0.014 * *$ \\
\hline Prior returns & -0.191 & 0.030 & -0.191 & 0.0149 & $0.096 *$ \\
\hline \multicolumn{6}{|l|}{ France } \\
\hline Cash Flow & 0.083 & 0.199 & 0.105 & 0.076 & 0.769 \\
\hline FCF Dummy & 0.178 & 0.384 & 0.363 & 0.483 & $0.000 * *$ \\
\hline Dividend Payout & 0.168 & 1.026 & 8.311 & 13.428 & $0.000 * *$ \\
\hline Dividend Yield & 1.695 & 2.114 & 1.709 & 1.631 & 0.132 \\
\hline Leverage & 0.222 & 0.180 & 0.220 & 0,144 & 0.616 \\
\hline MKBK & 5.202 & 27.714 & 3.013 & 3.378 & 0.106 \\
\hline SIZE & 11.166 & 1.818 & 14.094 & 2.312 & $0.000 * *$ \\
\hline ROA & -0.002 & 0.148 & 0.028 & 0.097 & 0.741 \\
\hline KZ- index & 0.416 & 1.124 & 0.790 & 0.891 & 0.458 \\
\hline Abnormal accruals & -0.058 & 0.032 & -0.051 & 0.0416 & $0.043^{*}$ \\
\hline Prior returns & -0.017 & 0.022 & -0.012 & 0.018 & 0.727 \\
\hline \multicolumn{6}{|l|}{ Germany } \\
\hline Cash Flow & 0.082 & 0.099 & 0.106 & 0.088 & $0.044 *$ \\
\hline FCF Dummy & 0.318 & 0.467 & 0.326 & 0.470 & 0.894 \\
\hline Dividend Payout & 0.373 & 1.340 & 1.103 & 2.669 & $0.025^{*}$ \\
\hline Dividend Yield & 1.408 & 1.703 & 1.577 & 1.625 & 0.224 \\
\hline Leverage & 0.190 & 0.170 & 0.138 & 0.140 & 0.066 \\
\hline MKBK & 2.621 & 2.224 & 2.941 & 2.180 & 0.056 \\
\hline SIZE & 11.653 & 1.811 & 13.197 & 2.251 & $0.000 * *$ \\
\hline ROA & -0.009 & 0.101 & 0.026 & 0.084 & $0.002 * *$ \\
\hline KZ-index & -0.135 & 2.188 & 0.509 & 0.923 & 0.113 \\
\hline Abnormal accruals & -0.057 & 0.024 & -0.056 & 0.031 & $0.041 *$ \\
\hline Prior returns & -0.011 & 0.016 & -0.006 & 0.011 & 0.204 \\
\hline \multicolumn{6}{|l|}{ All countries } \\
\hline Cash Flow & -0.016 & 0.872 & 0.108 & 0,092 & $0.000 * *$ \\
\hline FCF Dummy & 0.224 & 0.417 & 0.353 & 0,478 & $0.000 * *$ \\
\hline Dividend Payout & 0.340 & 1.512 & 3.658 & 8,751 & $0.000 * *$ \\
\hline Dividend Yield & 1.757 & 2.120 & 2.329 & 2,329 & $0.000 * *$ \\
\hline Leverage & 0.205 & 0.257 & 0.200 & 0,162 & 0.241 \\
\hline MKBK & 3.371 & 16.504 & 2.221 & 11,780 & 0.157 \\
\hline SIZE & 11.344 & 2.138 & 13.844 & 2,416 & $0.000^{* *}$ \\
\hline ROA & -0.056 & 0.447 & 0.030 & 0,124 & $0.000 * *$ \\
\hline KZ-index & 0.304 & 1.847 & 0.269 & 2.429 & 0.919 \\
\hline Abnormal accruals & -0.051 & 0.033 & -0.049 & 0.029 & $0.043 *$ \\
\hline Prior returns & -0.017 & 0.025 & -0.014 & 0.016 & 0.887 \\
\hline
\end{tabular}

Note: This table reports the descriptive statistics for the independent variables used in this study. The variables are defined in Appendix 1. ***,**, and * indicate statistical significance at the 1,5 , and $10 \%$ level respectively. 
Table 3: Logistic regression results

\begin{tabular}{|c|c|c|c|c|c|c|c|c|}
\hline \multirow[t]{2}{*}{ Panel A } & \multicolumn{4}{|c|}{ Specification 1} & \multicolumn{4}{|c|}{ Specification 2} \\
\hline & UK & France & Germany & $\begin{array}{c}\text { All } \\
\text { countries }\end{array}$ & UK & France & Germany & $\begin{array}{c}\text { All } \\
\text { countries }\end{array}$ \\
\hline \multirow[t]{2}{*}{ Cash Flow } & $2.133^{*}$ & 1.563 & -0.119 & 1.041 & 2.500 & 7.064 & 7.369 & 2.336 \\
\hline & $(0.054)$ & $(0.366)$ & $(0.941)$ & $(0.146)$ & $(0.148)$ & $(0.373)$ & $(0.413)$ & $(0.143)$ \\
\hline \multirow[t]{2}{*}{ FCF Dummy } & $0.648^{* *}$ & 0.258 & -0.356 & 0.132 & 0.027 & $2.298^{* *}$ & 0.376 & 0.416 \\
\hline & $(0.019)$ & $(0.474)$ & $(0.303)$ & $(0.450)$ & $(0.951)$ & $(0.017)$ & $(0.622)$ & $(0.169)$ \\
\hline \multirow[t]{2}{*}{ Dividend Payout } & 0.029 & $0.345^{* *_{*}^{*}}$ & $0.145^{* *}$ & $0.106^{* * * *}$ & 0.033 & $3.601^{* *}$ & 0.394 & $0.126^{* *}$ \\
\hline & $(0.475)$ & $(0.003)$ & $(0.048)$ & $(0.000)$ & $(0.604)$ & $(0.044)$ & $(0.111)$ & $(0.018)$ \\
\hline \multirow[t]{2}{*}{ Dividend Yield } & $0.087^{*}$ & $-0.176^{*}$ & -0.141 & 0.015 & -0.034 & -0.312 & -0.338 & -0.050 \\
\hline & $(0.078)$ & $(0.064)$ & $(0.141)$ & $(0.668)$ & $(0.718)$ & $(0.209)$ & $(0.173)$ & $(0.472)$ \\
\hline \multirow[t]{2}{*}{ Leverage } & -0.840 & -0.812 & $-2.864^{* * * *}$ & $-1.618^{* *_{*}^{* *}}$ & -0.612 & -4.324 & -0.949 & -1.431 \\
\hline & $(0.221)$ & $(0.436)$ & $(0.003)$ & $(0.001)$ & $(0.615)$ & $(0.203)$ & $(0.759)$ & $(0.129)$ \\
\hline \multirow[t]{2}{*}{ MKBK } & -0.009 & -0.001 & 0.048 & -0.004 & -0.003 & 0.022 & 0.192 & 0.002 \\
\hline & $(0.369)$ & $(0.958)$ & $(0.473)$ & $(0.604)$ & $(0.793)$ & $(0.926)$ & $(0.530)$ & $(0.866)$ \\
\hline \multirow[t]{2}{*}{ SIZE } & $0.422^{* * *}$ & $0.587^{* * * *}$ & $0.433^{* * * *}$ & $0.451^{* * * *}$ & $0.426^{* * *}$ & $0.840^{*}$ & $0.529^{* *}$ & $0.442^{*}$ \\
\hline & $(0.000)$ & $(0.000)$ & $(0.000)$ & $(0.000)$ & $(0.000)$ & $(0.001)$ & $(0.016)$ & $(0.000)$ \\
\hline \multirow[t]{2}{*}{ ROA } & -0.394 & 1.640 & $3.880^{* *}$ & 0.600 & -0.578 & 5.972 & $8.824^{*}$ & 0.321 \\
\hline & $(0.499)$ & $(0.234)$ & $(0.022)$ & $(0.333)$ & $(0.564)$ & $(0.428)$ & $(0.076)$ & $(0.759)$ \\
\hline \multirow[t]{2}{*}{ KZ-index } & & & & & 0.096 & 0.234 & 0.369 & $0.110^{\text {**** }}$ \\
\hline & & & & & $(0.160)$ & $(0.658)$ & $(0.322)$ & $(0.079)$ \\
\hline \multirow{2}{*}{$\begin{array}{l}\text { Abnormal } \\
\text { accruals }\end{array}$} & & & & & -3.096 & -10.953 & 3.022 & -0.248 \\
\hline & & & & & $(0.700)$ & $(0.512)$ & $(0.838)$ & $(0.958)$ \\
\hline \multirow[t]{2}{*}{ Prior returns } & & & & & -2.092 & $66.470^{* *}$ & 32.490 & 11.429 \\
\hline & & & & & $(0.856)$ & $(0.016)$ & $(0.295)$ & $(0.191)$ \\
\hline \multirow[t]{2}{*}{ Constant } & $-5.782^{* * *}$ & $-7.464^{* * * *}$ & $-4.825^{* * *}$ & $-5.613^{* * * *}$ & $-5.580^{* * * *}$ & $-12.196^{* * * *}$ & $-8.002^{* *}$ & $-5.810^{*}$ \\
\hline & $(0.000)$ & $(0.000)$ & $(0.000)$ & $(0.000)$ & $(0.000)$ & $(0.003)$ & $(0.020)$ & $(0.000)$ \\
\hline Pseudo - $R^{2}$ & 37.40 & 54.10 & 27.50 & 36.20 & 30.7 & 76.00 & 44.50 & 36.40 \\
\hline Obs.-Estimation & 380 & 292 & 258 & 930 & 130 & 84 & 55 & 269 \\
\hline Obs.-Holdout & 1,392 & 482 & 502 & 2,376 & 719 & 384 & 349 & 1,452 \\
\hline \multicolumn{3}{|l|}{ Panel B } & \multicolumn{4}{|c|}{ Classification and Predictive Accuracies } & & \\
\hline \multicolumn{5}{|c|}{ Estimation sample (\%) } & & & & \\
\hline Group 1 & 70.53 & 83.6 & 67.4 & 76.6 & 66.10 & 90.50 & 70.40 & 72.52 \\
\hline Group 2 & 75.79 & 75.3 & 64.3 & 69.2 & 75.00 & 88.10 & 78.60 & 73.2 \\
\hline Average & 73.16 & 79.45 & 65.85 & 72.9 & 70.55 & 89.30 & 74.50 & 72.9 \\
\hline \multicolumn{9}{|c|}{ Holdout sample (\%) } \\
\hline Group 1 & 86.18 & 77.7 & 69 & 83.3 & 87.60 & 90.10 & 38.50 & 81.00 \\
\hline Group 2 & 76.92 & 70 & 63.6 & 71.4 & 28.20 & 13.30 & 86.40 & 59.30 \\
\hline Average & 81.55 & 73.85 & 66.3 & 77.35 & 57.90 & 51.70 & 62.45 & 70.15 \\
\hline \multicolumn{9}{|c|}{$\begin{array}{l}\text { Notes: This table presents results from the logit regressions for each country and for the pooled-samples (all- } \\
\text { countries). The dependent variable is a binary variable equal to one for firms that make a share repurchase } \\
\text { announcements and zero otherwise, over the period } 1997 \text { to } 2006 \text {. Financial firms are excluded from the samples. All } \\
\text { explanatory variables are defined in Appendix } 1 \text {. Panel A reports the logit-model coefficient estimate. The p-values of } \\
\text { the coefficient estimates are reported in parentheses. Panel B reports the respective classification accuracies of each } \\
\text { logit specification. } * * * * * \text {, and } * \text { indicate statistical significance at the } 1,5 \text {, and } 10 \% \text { level, respectively. }\end{array}$} \\
\hline
\end{tabular}


Table 4: Portfolios' Performance - Buy-and-Hold-Abnormal-Returns

\begin{tabular}{|c|c|c|c|c|c|c|c|c|}
\hline \multirow[t]{2}{*}{ Panel A } & \multicolumn{8}{|c|}{$\begin{array}{l}\text { Holding Periods (in months) } \\
\text { Total sample }\end{array}$} \\
\hline & $1 \mathrm{~m}$ & $2 \mathrm{~m}$ & $3 \mathrm{~m}$ & $6 \mathrm{~m}$ & $9 \mathrm{~m}$ & $12 \mathrm{~m}$ & $15 \mathrm{~m}$ & $18 \mathrm{~m}$ \\
\hline UK & $\begin{array}{c}1.55 \% \\
(0.000)\end{array}$ & $\begin{array}{c}1.02 \%{ }^{* * *} \\
(0.000)\end{array}$ & $\begin{array}{c}1.28 \% \\
(0.000)\end{array}$ & $\begin{array}{c}0.94 \% \\
(0.000)\end{array}$ & $\begin{array}{c}0.09 \% \\
(0.348)\end{array}$ & $\begin{array}{c}0.22 \% \\
(0.148)\end{array}$ & $\begin{array}{c}-1.47 \%^{* * *} \\
(0.000)\end{array}$ & $\begin{array}{c}-1.22 \%^{* * * *} \\
(0.000)\end{array}$ \\
\hline France & $\begin{array}{c}0.77 \% \\
(0.000)\end{array}$ & $\begin{array}{c}7.72 \%{ }^{* * * *} \\
(0.000)\end{array}$ & $\begin{array}{c}8.84 \%^{* * * *} \\
(0.000)\end{array}$ & $\begin{array}{c}14.68 \% \\
(0.000)\end{array}$ & $\begin{array}{c}11.39 \% \\
(0.000)\end{array}$ & $\begin{array}{c}12.34 \% \\
(0.000)\end{array}$ & $\begin{array}{c}17.58 \% \\
(0.000)\end{array}$ & $\begin{array}{c}31.76 \% \\
(0.000)\end{array}$ \\
\hline Germany & $\begin{array}{c}0.87 \% \\
(0.000)\end{array}$ & $\begin{array}{c}3.46 \% \\
(0.000)\end{array}$ & $\begin{array}{c}4.12 \%{ }^{* * * *} \\
(0.000)\end{array}$ & $\begin{array}{c}6.14 \%{ }^{* * *} \\
(0.000)\end{array}$ & $\begin{array}{c}5.88 \%{ }^{* * * *} \\
(0.000)\end{array}$ & $\begin{array}{c}3.92 \%{ }^{* * * *} \\
(0.000)\end{array}$ & $\begin{array}{c}8.06 \% \\
(0.000)\end{array}$ & $\begin{array}{c}4.51 \% \\
(0.000)\end{array}$ \\
\hline $\begin{array}{l}\text { All } \\
\text { countries }\end{array}$ & $\begin{array}{c}1.14 \% \\
(0.000)\end{array}$ & $\begin{array}{c}3.43 \% \\
(0.000)\end{array}$ & $\begin{array}{c}4.02 \%{ }^{* * * *} \\
(0.000)\end{array}$ & $\begin{array}{c}5.93 \% \\
(0.000) \\
\end{array}$ & $\begin{array}{c}4.68 \%{ }^{* * *} \\
(0.000)\end{array}$ & $\begin{array}{c}4.34 \%^{* * * *} \\
(0.000)\end{array}$ & $\begin{array}{c}6.19 \%^{* * * *} \\
(0.000)\end{array}$ & $\begin{array}{c}8.63 \% \%^{* * * *} \\
(0.000)\end{array}$ \\
\hline Panel B & \multicolumn{8}{|c|}{ Above median MKBK } \\
\hline & $1 \mathrm{~m}$ & $2 \mathrm{~m}$ & $3 m$ & $6 \mathrm{~m}$ & $9 \mathrm{~m}$ & $12 \mathrm{~m}$ & $15 \mathrm{~m}$ & $18 \mathrm{~m}$ \\
\hline UK & $\begin{array}{c}1.15 \% \%^{* * * *} \\
(0.000)\end{array}$ & $\begin{array}{c}1.39 \% \\
(0.000)\end{array}$ & $\begin{array}{c}1.09 \%^{\text {**** }} \\
(0.000)\end{array}$ & $\begin{array}{c}0.48 \%^{* * *} \\
(0.004)\end{array}$ & $\begin{array}{c}-1.54 \%^{* * *} \\
(0.000)\end{array}$ & $\begin{array}{c}-3.98 \% \\
(0.000)\end{array}$ & $\begin{array}{c}-6.36 \% \\
(0.000)\end{array}$ & $\begin{array}{c}-5.09 \% \\
(0.000)\end{array}$ \\
\hline France & $\begin{array}{l}2.50 \%{ }^{* * * *} \\
(0.000)\end{array}$ & $\begin{array}{l}4.84 \%^{* * *} \\
(0.000)\end{array}$ & $\begin{array}{c}5.05 \% \\
(0.000)\end{array}$ & $\begin{array}{l}5.35 \% \\
(0.000)\end{array}$ & $\begin{array}{l}1.55 \% \\
(0.000)\end{array}$ & $\begin{array}{l}0.291 \% \\
(0.591)\end{array}$ & $\begin{array}{l}2.24 \%^{* * *} \\
(0.000)\end{array}$ & $\begin{array}{l}0.37 \% \\
(0.551)\end{array}$ \\
\hline Germany & $\begin{array}{l}0.36 \% \\
(0.027)\end{array}$ & $\begin{array}{c}5.04 \% \\
(0.000)\end{array}$ & $\begin{array}{c}6.90 \% \\
(0.000)\end{array}$ & $\begin{array}{c}6.14 \%^{* * *} \\
(0.000)\end{array}$ & $\begin{array}{l}1.97 \%{ }^{* * *} \\
(0.001)\end{array}$ & $\begin{array}{c}-2.02 \% \\
(0.003)\end{array}$ & $\begin{array}{c}4.86 \% \\
(0.000)\end{array}$ & $\begin{array}{c}0.64 \% \\
(0.511)\end{array}$ \\
\hline $\begin{array}{l}\text { All } \\
\text { countries }\end{array}$ & $\begin{array}{c}1.26 \% \\
(0.000)\end{array}$ & $\begin{array}{c}3.24 \% \\
(0.000)\end{array}$ & $\begin{array}{c}3.73 \% \\
(0.000)\end{array}$ & $\begin{array}{c}3.28 \%^{* * * *} \\
(0.000)\end{array}$ & $\begin{array}{c}0.07 \% \\
(0.597)\end{array}$ & $\begin{array}{c}-2.86 \% \\
(0.000)\end{array}$ & $\begin{array}{c}-1.30 \% \\
(0.000)\end{array}$ & $\begin{array}{c}-2.69 \% \\
(0.000)\end{array}$ \\
\hline & \multicolumn{8}{|c|}{ Below median MKBK } \\
\hline & $1 \mathrm{~m}$ & $2 \mathrm{~m}$ & $3 \mathrm{~m}$ & $6 \mathrm{~m}$ & $9 \mathrm{~m}$ & $12 \mathrm{~m}$ & $15 \mathrm{~m}$ & $18 \mathrm{~m}$ \\
\hline UK & $\begin{array}{c}1.94 \% \\
(0.000)\end{array}$ & $\begin{array}{c}0.66 \% \\
(0.000)\end{array}$ & $\begin{array}{c}1.46 \% \\
(0.000)\end{array}$ & $\begin{array}{c}1.39 \% \\
(0.000)\end{array}$ & $\begin{array}{c}1.71 \%{ }^{* * *} \\
(0.000)\end{array}$ & $\begin{array}{c}4.39 \%^{\text {**** }} \\
(0.000)\end{array}$ & $\begin{array}{c}3.38 \%{ }^{* * * *} \\
(0.000)\end{array}$ & $\begin{array}{c}2.61 \%{ }^{* * * *} \\
(0.000)\end{array}$ \\
\hline France & $\begin{array}{c}-0.96 \% \\
(0.000)\end{array}$ & $\begin{array}{c}10.60 \% \\
(0.000)\end{array}$ & $\begin{array}{c}12.64 \% \\
(0.000)\end{array}$ & $\begin{array}{c}24.01 \%^{\text {**** }} \\
(0.000)\end{array}$ & $\begin{array}{c}21.24 \% \\
(0.000)\end{array}$ & $\begin{array}{c}24.38 \% \\
(0.000)\end{array}$ & $\begin{array}{c}32.92 \% \\
(0.000)\end{array}$ & $\begin{array}{c}63.15 \% \\
(0.000)\end{array}$ \\
\hline Germany & $\begin{array}{c}1.35 \% \\
(0.000\end{array}$ & $\begin{array}{c}1.96 \% \\
(0.000)\end{array}$ & $\begin{array}{l}1.49 \% \\
(0.000)\end{array}$ & $\begin{array}{l}6.14 \%^{* * *} \\
(0.000)\end{array}$ & $\begin{array}{l}9.60 \% \\
(0.000)\end{array}$ & $\begin{array}{l}9.57 \% \%^{* * *} \\
(0.000)\end{array}$ & $\begin{array}{c}11.10 \% \\
(0.000)\end{array}$ & $\begin{array}{c}8.20 \% \\
(0.000)\end{array}$ \\
\hline $\begin{array}{l}\text { All } \\
\text { countries }\end{array}$ & $\begin{array}{c}1.05 \% \\
(0.000)\end{array}$ & $\begin{array}{c}3.47 \%^{* * * *} \\
(0.000)\end{array}$ & $\begin{array}{c}4.16 \%^{\text {***** }} \\
(0.000)\end{array}$ & $\begin{array}{c}8.37 \%^{* * * *} \\
(0.000)\end{array}$ & $\begin{array}{c}8.96 \% \\
(0.000)\end{array}$ & $\begin{array}{c}10.87 \%^{* * * *} \\
(0.000) \\
\end{array}$ & $\begin{array}{c}12.98 \%^{* * * *} \\
(0.000) \\
\end{array}$ & $\begin{array}{c}18.99 \%^{* * * *} \\
(0.000)\end{array}$ \\
\hline Panel C & \multicolumn{8}{|c|}{ Above Median Size } \\
\hline & $1 \mathrm{~m}$ & $2 \mathrm{~m}$ & $3 \mathrm{~m}$ & $6 \mathrm{~m}$ & $9 \mathrm{~m}$ & $12 \mathrm{~m}$ & $15 \mathrm{~m}$ & $18 \mathrm{~m}$ \\
\hline UK & $\begin{array}{c}1.08 \% \\
(0.000)\end{array}$ & $\begin{array}{c}1.02 \%^{* * *} \\
(0.000)\end{array}$ & $\begin{array}{c}1.76 \% \\
(0.000)\end{array}$ & $\begin{array}{c}1.23 \%^{* * *} \\
(0.000)\end{array}$ & $\begin{array}{c}2.21 \%^{* * *} \\
(0.000)\end{array}$ & $\begin{array}{c}5.60 \% \\
(0.000)\end{array}$ & $\begin{array}{c}6.99 \%{ }^{* * * *} \\
(0.000)\end{array}$ & $\begin{array}{c}6.04 \%^{* * *} \\
(0.000)\end{array}$ \\
\hline France & $\begin{array}{c}2.22 \% \\
(0.000)\end{array}$ & $\begin{array}{c}3.63 \%^{* * * *} \\
(0.000)\end{array}$ & $\begin{array}{c}5.61 \% \\
(0.000)\end{array}$ & $\begin{array}{c}6.14 \%{ }^{* * * *} \\
(0.000)\end{array}$ & $\begin{array}{c}5.01 \%{ }^{* * *} \\
(0.000)\end{array}$ & $\begin{array}{c}5.39 \% \\
(0.000)\end{array}$ & $\begin{array}{c}6.69 \% \\
(0.000)\end{array}$ & $\begin{array}{c}3.13 \% \\
(0.000)\end{array}$ \\
\hline Germany & $\begin{array}{c}0.11 \% \\
(0.420)\end{array}$ & $\begin{array}{l}1.01 \%^{* * * *} \\
(0.000)\end{array}$ & $\begin{array}{c}0.24 \% \\
(0.275)\end{array}$ & $\begin{array}{c}4.01 \%{ }^{* * * *} \\
(0.000)\end{array}$ & $\begin{array}{l}7.40 \%^{* * * *} \\
(0.000)\end{array}$ & $\begin{array}{c}11.24 \% \\
(0.000)\end{array}$ & $\begin{array}{c}14.81 \% \text { **** } \\
(0.000)\end{array}$ & $\begin{array}{c}16.78 \% \\
(0.000)\end{array}$ \\
\hline $\begin{array}{l}\text { All } \\
\text { countries }\end{array}$ & $\begin{array}{c}1.05 \% \\
(0.000)\end{array}$ & $\begin{array}{c}1.65 \% \\
(0.000)\end{array}$ & $\begin{array}{c}2.23 \% \\
(0.000)\end{array}$ & $\begin{array}{c}3.31 \%{ }^{* * * *} \\
(0.000)\end{array}$ & $\begin{array}{c}4.53 \%^{* * * *} \\
(0.000)\end{array}$ & $\begin{array}{c}7.33 \%{ }^{* * * *} \\
(0.000)\end{array}$ & $\begin{array}{c}9.38 \% \\
(0.000)\end{array}$ & $\begin{array}{c}8.72 \% \\
(0.000)\end{array}$ \\
\hline & \multicolumn{8}{|c|}{ Below Median Size } \\
\hline & $1 \mathrm{~m}$ & $2 \mathrm{~m}$ & $3 \mathrm{~m}$ & $6 \mathrm{~m}$ & $9 \mathrm{~m}$ & $12 \mathrm{~m}$ & $15 \mathrm{~m}$ & $18 \mathrm{~m}$ \\
\hline UK & $\begin{array}{c}2.01 \%{ }^{* * *} \\
(0.000)\end{array}$ & $\begin{array}{c}1.02 \%{ }^{* * * *} \\
(0.000)\end{array}$ & $\begin{array}{c}0.80 \% \\
(0.000)\end{array}$ & $\begin{array}{c}0.64 \%^{* * * *} \\
(0.000)\end{array}$ & $\begin{array}{c}-2.01 \%^{\text {**** }} \\
(0.000)\end{array}$ & $\begin{array}{c}-5.10 \%^{\text {**** }} \\
(0.000)\end{array}$ & $\begin{array}{c}-9.85 \% \\
(0.000)\end{array}$ & $\begin{array}{c}-8.42 \%{ }^{* * * *} \\
(0.000)\end{array}$ \\
\hline France & $\begin{array}{c}-0.68 \% \\
(0.008)\end{array}$ & $\begin{array}{c}11.82 \% \\
(0.000)\end{array}$ & $\begin{array}{c}12.07 \% \\
(0.000)\end{array}$ & $\begin{array}{c}23.22 \%^{* * * *} \\
(0.000)\end{array}$ & $\begin{array}{c}17.78 \% \\
(0.000)\end{array}$ & $\begin{array}{c}19.28 \% \\
(0.000)\end{array}$ & $\begin{array}{c}28.47 \% \\
(0.000)\end{array}$ & $\begin{array}{c}60.40 \% \\
(0.000)\end{array}$ \\
\hline Germany & $\begin{array}{c}1.61 \% \\
(0.000)\end{array}$ & $\begin{array}{c}5.85 \% \\
(0.000)\end{array}$ & $\begin{array}{c}7.90 \% \\
(0.000)\end{array}$ & $\begin{array}{c}8.22 \% \\
(0.000)\end{array}$ & $\begin{array}{l}4.40 \% \\
(0.000)\end{array}$ & $\begin{array}{c}-3.21 \% \\
(0.000)\end{array}$ & $\begin{array}{l}1.49 \% \\
(0.067)\end{array}$ & $\begin{array}{c}-7.44 \% \\
(0.000)\end{array}$ \\
\hline $\begin{array}{l}\text { All } \\
\text { countries }\end{array}$ & $\begin{array}{c}1.23 \% \\
(0.000)\end{array}$ & $\begin{array}{c}5.18 \%^{\text {**** }} \\
(0.000)\end{array}$ & $\begin{array}{c}5.79 \% \\
(0.000)\end{array}$ & $\begin{array}{c}8.53 \%^{* * * *} \\
(0.000)\end{array}$ & $\begin{array}{c}4.83 \%^{* * * *} \\
(0.000)\end{array}$ & $\begin{array}{c}1.40 \% \\
(0.000)\end{array}$ & $\begin{array}{c}3.04 \% \\
(0.000)\end{array}$ & $\begin{array}{c}8.54 \% \\
(0.000)\end{array}$ \\
\hline Notes: This & le presents & buy and ho & abnormal $\mathrm{r}$ & ns, across a & imber of ho & $\begin{array}{l}\text { g monthly- } \\
\text { dels of Sp } \\
\text { Yield, Lever } \\
\text { ntheses. ** }\end{array}$ & $\begin{array}{l}\text { iods }(\mathrm{m}) \text {, of } \\
\text { ication } 1 . \\
\text { MKBK, }\end{array}$ & $\begin{array}{l}\text { rtfolios that } \\
\text { cification } 1 \\
\text {, ROA. All } \\
\text { e statistical }\end{array}$ \\
\hline
\end{tabular}


Table 5: Fama and MacBeth (1973) regressions

\begin{tabular}{|c|c|c|c|c|c|c|c|c|c|c|c|c|}
\hline & \multicolumn{12}{|c|}{ United Kingdom } \\
\hline \multirow{2}{*}{$\beta$} & \multicolumn{2}{|c|}{$1 \mathrm{~m}$} & \multicolumn{2}{|c|}{$3 m$} & \multicolumn{2}{|c|}{$6 \mathrm{~m}$} & \multicolumn{2}{|c|}{$9 m$} & \multicolumn{2}{|c|}{$12 \mathrm{~m}$} & \multicolumn{2}{|c|}{$18 \mathrm{~m}$} \\
\hline & 0.058 & $0.097 *$ & 0.257 & 0.170 & 0.023 & 0.207 & 0.190 & 0.037 & 0.304 & -0.051 & 0.208 & -0.083 \\
\hline & $(0.476)$ & $(1.791)$ & $(1.375)$ & $(1.608)$ & $(0.101)$ & $(1.473)$ & $(0.723)$ & $(0.260)$ & $(0.689)$ & $(-0.299)$ & $(0.385)$ & $(-0.376)$ \\
\hline \multirow{2}{*}{$\beta^{2}$} & -0.025 & $-0.091 * *$ & -0.184 & $-0.166 * * *$ & 0.054 & -0.140 & -0.134 & 0.006 & -0.213 & 0.078 & -0.027 & 0.185 \\
\hline & $(-0.253)$ & $(-2.317)$ & $(-1.092)$ & $(-2.649)$ & $(0.260)$ & $(-1.541)$ & $(-0.574)$ & $(0.065)$ & $(-0.543)$ & $(0.633)$ & $(-0.061)$ & $(1.160)$ \\
\hline \multirow[t]{2}{*}{ s } & $3.609 * *$ & $5.486 * *$ & $5.150 * *$ & $12.232 * *$ & $6.546^{* *}$ & $11.589^{*}$ & 3.943 & 0.372 & 2.090 & -2.870 & 10.649 & -4.587 \\
\hline & $(2.027)$ & $(2.415)$ & $(1.981)$ & $(2.601)$ & $(1.975)$ & $(1.885)$ & $(0.989)$ & $(0.050)$ & $(0.331)$ & $(-0.308)$ & (1.294) & $(-0.376)$ \\
\hline \multirow[t]{2}{*}{ Cash Flow } & 0.005 & 0.061 & 0.150 & -0.095 & 0.262 & -0.071 & 0.160 & $0.957 * * *$ & 0.097 & 0.611 & 0.400 & 0.930 \\
\hline & $(0.049)$ & $(0.408)$ & $(0.906)$ & $(-0.387)$ & $(1.240)$ & $(-0.217)$ & $(0.752)$ & $(2.657)$ & $(0.252)$ & $(1.203)$ & $(0.779)$ & (1.634) \\
\hline \multirow[t]{2}{*}{ FCF Dummy } & 0.000 & -0.005 & -0.007 & 0.017 & -0.030 & 0.060 & -0.045 & 0.005 & -0.028 & 0.060 & -0.062 & 0.053 \\
\hline & $(-0.026)$ & $(-0.226)$ & $(-0.364)$ & $(0.436)$ & $(-1.166)$ & (1.067) & $(-1.464)$ & $(0.074)$ & $(-0.544)$ & $(0.803)$ & $(-0.999)$ & $(0.498)$ \\
\hline \multirow[t]{2}{*}{ Div Payout } & $0.002 * * *$ & $0.003 * * *$ & 0.000 & 0.000 & -0.001 & 0.001 & 0.000 & 0.001 & -0.002 & 0.000 & $-0.005^{*}$ & -0.004 \\
\hline & (3.209) & (3.634) & $(0.221)$ & (0.095) & $(-0.241)$ & $(0.256)$ & $(-0.096)$ & $(0.338)$ & $(-0.704)$ & $(0.065)$ & $(-1.682)$ & $(-0.811)$ \\
\hline \multirow[t]{2}{*}{ Div Yield } & $-0.004 * *$ & -0.007 & -0.005 & -0.005 & -0.007 & -0.012 & $-0.014^{*}$ & -0.004 & $-0.033^{*}$ & $-0.057 * *$ & -0.036 & -0.032 \\
\hline & $(-2.111)$ & $(-0.760)$ & $(-1.500)$ & $(-0.336)$ & $(-1.102)$ & $(-0.654)$ & $(-1.731)$ & $(-0.147)$ & $(-1.721)$ & $(-1.990)$ & $(-1.445)$ & $(-0.786)$ \\
\hline \multirow{2}{*}{ Leverage } & -0.047 & 0.000 & $-0.144 * *$ & 0.063 & $-0.174 * *$ & -0.019 & -0.128 & -0.007 & 0.038 & 0.536 & -0.094 & 0.614 \\
\hline & $(-1.340)$ & $(-0.001)$ & $(-2.270)$ & $(0.367)$ & $(-2.098)$ & $(-0.077)$ & $(-1.527)$ & $(-0.029)$ & $(0.285)$ & $(1.584)$ & $(-0.604)$ & $(1.573)$ \\
\hline \multirow[t]{2}{*}{ MKBK } & -0.001 & 0.002 & 0.000 & $0.007 *$ & 0.000 & $0.013 * *$ & 0.000 & $0.014 *$ & 0.000 & $0.022 * *$ & 0.000 & 0.017 \\
\hline & $(-1.646)$ & $(0.928)$ & $(-0.061)$ & (1.785) & $(0.526)$ & $(2.023)$ & $(0.529)$ & (1.757) & $(-0.240)$ & $(2.026)$ & $(-0.056)$ & (1.527) \\
\hline \multirow[t]{2}{*}{ Size } & -0.001 & 0.005 & 0.005 & 0.015 & 0.010 & 0.020 & 0.012 & 0.011 & 0.019 & 0.022 & 0.033 & 0.021 \\
\hline & $(-0.188)$ & $(0.902)$ & $(0.652)$ & (1.389) & $(1.195)$ & $(1.464)$ & $(1.069)$ & $(0.735)$ & $(1.260)$ & (1.173) & $(1.547)$ & $(0.846)$ \\
\hline \multirow{2}{*}{ ROA } & 0.036 & 0.012 & -0.248 & 0.095 & $-0.501 * *$ & -0.062 & $-0.497 * *$ & $-1.015^{* * *}$ & -0.682 & -0.656 & $-1.190 *$ & $-1.048 * *$ \\
\hline & $(0.316)$ & $(0.092)$ & $(-1.444)$ & $(0.433)$ & $(-2.239)$ & $(-0.217)$ & $(-2.056)$ & $(-2.974)$ & $(-1.349)$ & $(-1.438)$ & $(-1.753)$ & $(-2.022)$ \\
\hline \multirow{2}{*}{ KZ Index } & -0.204 & 0.000 & -0.336 & -0.017 & $-0.565^{*}$ & -0.029 & -0.304 & -0.010 & -0.198 & -0.082 & -0.991 & $-0.104 * *$ \\
\hline & $(-1.235)$ & $(-0.029)$ & $(-1.355)$ & $(-0.831)$ & $(-1.767)$ & $(-0.938)$ & $(-0.806)$ & $(-0.278)$ & $(-0.347)$ & $(-1.573)$ & $(-1.300)$ & $(-2.035)$ \\
\hline \multirow{2}{*}{$\begin{array}{r}\text { Abnormal } \\
\text { Accruals }\end{array}$} & & -0.010 & & -0.040 & & -0.138 & & $-0.243 * *$ & & $-0.268 *$ & & $-0.276^{*}$ \\
\hline & & $(-0.222)$ & & $(-0.466)$ & & $(-1.388)$ & & $(-2.448)$ & & $(-1.918)$ & & $(-1.691)$ \\
\hline \multirow[t]{2}{*}{ Past returns } & & 0.253 & & 3.861 & & 1.682 & & -0.099 & & 0.231 & & 3.799 \\
\hline & & $(0.228)$ & & $(1.491)$ & & $(0.443)$ & & $(-0.025)$ & & $(0.053)$ & & $(0.644)$ \\
\hline \multirow[t]{2}{*}{ Constant } & & $-0.424 * *$ & & $-0.992 * *$ & & $-1.136^{* *}$ & & -0.309 & & -0.168 & & -0.108 \\
\hline & & $(-2.474)$ & & $(-2.583)$ & & $(-2.286)$ & & $(-0.482)$ & & $(-0.206)$ & & $(-0.097)$ \\
\hline Obs. & 213 & 95 & 213 & 95 & 213 & 95 & 213 & 95 & 213 & 95 & 213 & 95 \\
\hline Adj. $\mathrm{R}^{2}(\%)$ & 1.30 & 2.23 & 0.24 & 1.38 & 3.13 & 1.67 & 4.25 & 2.69 & 8.61 & 6.61 & 9.49 & 4.86 \\
\hline $\begin{array}{l}\text { Notes: This tat } \\
\text { column indicat } \\
\text { regressions inc }\end{array}$ & 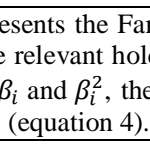 & $\mathrm{D}$ & 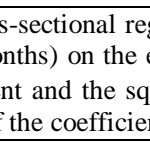 & 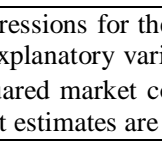 & 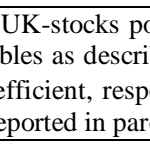 & 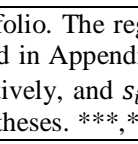 & 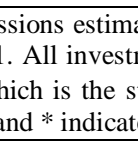 & 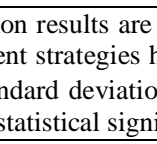 & 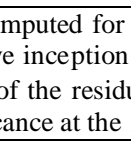 & 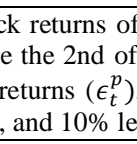 & $\begin{array}{l}\text { us hold } \\
\text { ary } 200 e\end{array}$ & $\begin{array}{l}\text { iods (each } \\
\text { dition, the }\end{array}$ \\
\hline
\end{tabular}


Table 5 continued.

\begin{tabular}{|c|c|c|c|c|c|c|c|c|c|c|c|c|}
\hline \multirow{4}{*}{$\beta$} & \multicolumn{12}{|c|}{ France } \\
\hline & \multicolumn{2}{|c|}{$1 \mathrm{~m}$} & \multicolumn{2}{|c|}{$3 m$} & \multicolumn{2}{|c|}{$6 \mathrm{~m}$} & \multicolumn{2}{|c|}{$9 \mathrm{~m}$} & \multicolumn{2}{|c|}{$12 \mathrm{~m}$} & \multicolumn{2}{|c|}{$18 \mathrm{~m}$} \\
\hline & -0.105 & -0.046 & -0.542 & -0.227 & -0.693 & -0.297 & -0.595 & $-0.578 * * *$ & -0.565 & $-0.512 *$ & -0.539 & -0.411 \\
\hline & $(-0.715)$ & $(-0.392)$ & $(-1.123)$ & $(-1.631)$ & $(-1.095)$ & $(-1.562)$ & $(-0.922)$ & $(-3.052)$ & $(-0.812)$ & $(-2.016)$ & $(-0.602)$ & $(-1.479)$ \\
\hline \multirow[t]{2}{*}{$\beta^{2}$} & 0.022 & -0.007 & 0.423 & -0.039 & 0.500 & -0.092 & 0.273 & -0.091 & 0.306 & -0.065 & 0.214 & -0.101 \\
\hline & $(0.147)$ & $(-0.286)$ & $(0.857)$ & $(-1.057)$ & $(0.776)$ & $(-1.431)$ & $(0.418)$ & $(-1.436)$ & $(0.437)$ & $(-0.932)$ & $(0.237)$ & $(-1.163)$ \\
\hline \multirow[t]{2}{*}{ s } & -1.114 & 0.721 & -3.138 & -0.792 & -2.364 & 1.626 & -3.116 & -2.505 & -0.831 & -0.500 & 1.757 & 0.971 \\
\hline & $(-0.874)$ & $(0.318)$ & $(-1.289)$ & $(-0.240)$ & $(-0.738)$ & $(0.272)$ & $(-0.906)$ & $(-0.416)$ & $(-0.214)$ & $(-0.086)$ & $(0.340)$ & $(0.126)$ \\
\hline \multirow[t]{2}{*}{ Cash Flow } & -0.042 & $-1.461 * * *$ & -0.439 & -0.955 & -0.399 & -1.118 & -0.425 & -1.068 & -0.294 & -1.953 & -0.694 & -1.324 \\
\hline & $(-0.238)$ & $(-3.258)$ & $(-1.131)$ & $(-1.679)$ & $(-0.644)$ & $(-1.345)$ & $(-0.643)$ & $(-1.241)$ & $(-0.460)$ & $(-1.575)$ & $(-0.720)$ & $(-1.158)$ \\
\hline \multirow[t]{2}{*}{ FCF Dummy } & $-0.034 *$ & 0.014 & -0.046 & 0.039 & $-0.090^{*}$ & 0.009 & $-0.090 *$ & 0.013 & $-0.137 * *$ & 0.030 & $-0.131 *$ & -0.054 \\
\hline & $(-1.862)$ & $(0.400)$ & $(-1.254)$ & $(0.698)$ & $(-1.946)$ & $(0.091)$ & $(-1.871)$ & $(0.139)$ & $(-2.423)$ & $(0.284)$ & $(-1.814)$ & $(-0.410)$ \\
\hline \multirow[t]{2}{*}{ Div Payout } & $-0.002 * *$ & -0.002 & -0.002 & -0.002 & $-0.008 * *$ & $-0.007 * *$ & -0.007 & -0.003 & -0.006 & -0.004 & $-0.011 * *$ & $-0.006^{* *}$ \\
\hline & $(-2.032)$ & $(-1.279)$ & $(-1.124)$ & $(-1.126)$ & $(-2.386)$ & $(-2.635)$ & $(-1.498)$ & $(-1.212)$ & $(-1.573)$ & $(-1.505)$ & $(-2.364)$ & $(-2.645)$ \\
\hline \multirow[t]{2}{*}{ Div Yield } & $-0.019 * * *$ & -0.006 & $-0.046^{* * *}$ & -0.007 & $-0.046^{* *}$ & 0.002 & $-0.043 * *$ & -0.006 & $-0.059 * * *$ & -0.017 & $-0.047^{*}$ & 0.000 \\
\hline & $(-2.858)$ & $(-0.560)$ & $(-3.228)$ & $(-0.425)$ & $(-2.515)$ & $(0.071)$ & $(-2.281)$ & $(-0.283)$ & $(-2.697)$ & $(-0.574)$ & $(-1.733)$ & $(0.012)$ \\
\hline \multirow[t]{2}{*}{ Leverage } & 0.042 & 0.036 & 0.035 & 0.038 & 0.075 & 0.016 & 0.047 & -0.064 & -0.083 & -0.197 & -0.079 & -0.280 \\
\hline & $(0.890)$ & (0.673) & $(0.463)$ & $(0.355)$ & $(0.693)$ & $(0.090)$ & $(0.294)$ & $(-0.427)$ & $(-0.415)$ & $(-1.213)$ & $(-0.305)$ & $(-1.326)$ \\
\hline \multirow[t]{2}{*}{ MKBK } & 0.007 & $0.001 * * *$ & -0.007 & $0.001 *$ & -0.019 & 0.001 & -0.025 & 0.001 & -0.032 & 0.000 & -0.044 & 0.001 \\
\hline & (1.113) & $(3.559)$ & $(-0.717)$ & $(2.013)$ & $(-1.460)$ & $(1.101)$ & $(-1.402)$ & $(0.976)$ & $(-1.420)$ & $(-0.068)$ & $(-1.352)$ & $(0.758)$ \\
\hline \multirow[t]{2}{*}{ Size } & $0.013^{* *}$ & $0.032 * * *$ & 0.011 & $0.027 *$ & 0.007 & 0.017 & 0.023 & 0.025 & 0.033 & $0.044 *$ & 0.029 & 0.031 \\
\hline & $(2.281)$ & $(4.245)$ & $(0.771)$ & $(2.031)$ & $(0.362)$ & $(0.813)$ & (1.118) & (1.251) & (1.530) & $(1.835)$ & (1.059) & $(1.076)$ \\
\hline \multirow{2}{*}{ ROA } & 0.150 & $1.854 * * *$ & 1.347 & $1.514^{*}$ & 1.527 & 2.062 & 1.950 & $2.530^{*}$ & 1.705 & $3.945^{* *}$ & 2.178 & 2.741 \\
\hline & (1.010) & $(3.131)$ & $(1.612)$ & $(1.838)$ & $(1.206)$ & $(1.565)$ & (1.506) & (1.947) & (1.374) & $(2.357)$ & (1.198) & (1.664) \\
\hline \multirow[t]{2}{*}{ KZ Index } & 0.004 & -0.025 & 0.360 & -0.021 & 0.377 & -0.046 & 0.248 & -0.061 & 0.100 & -0.018 & 0.199 & -0.016 \\
\hline & $(0.032)$ & $(-0.864)$ & (1.082) & $(-0.489)$ & $(0.860)$ & $(-0.709)$ & $(0.540)$ & $(-1.109)$ & $(0.196)$ & $(-0.284)$ & $(0.304)$ & $(-0.233)$ \\
\hline \multirow{2}{*}{$\begin{array}{l}\text { Abnormal } \\
\text { Accruals }\end{array}$} & & -0.094 & & -0.128 & & -0.191 & & $-0.318 *$ & & -0.224 & & -0.296 \\
\hline & & $(-1.308)$ & & $(-1.151)$ & & $(-1.092)$ & & $(-2.063)$ & & $(-1.397)$ & & $(-1.608)$ \\
\hline \multirow[t]{2}{*}{ Past returns } & & -3.218 & & -0.723 & & 1.625 & & 5.476 & & 1.324 & & 5.950 \\
\hline & & $(-1.399)$ & & $(-0.207)$ & & $(0.354)$ & & (1.290) & & $(0.272)$ & & $(0.845)$ \\
\hline \multirow[t]{2}{*}{ Constant } & & -0.326 & & -0.009 & & 0.059 & & 0.423 & & 0.049 & & 0.312 \\
\hline & & $(-1.556)$ & & $(-0.029)$ & & $(0.125)$ & & (0.873) & & $(0.084)$ & & $(0.486)$ \\
\hline Obs. & 118 & 39 & 118 & 39 & 118 & 39 & 118 & 39 & 118 & 39 & 118 & 39 \\
\hline Adj. $R^{2}(\%)$ & 12.90 & 69.91 & 13.42 & 45.49 & 12.68 & 6.96 & 13.23 & 20.53 & 13.25 & 17.52 & 6.97 & 17.11 \\
\hline $\begin{array}{l}\text { Notes: This tab } \\
\text { column indicat } \\
\text { regressions incl }\end{array}$ & $\begin{array}{l}\text { ts the } \mathrm{Fa} \\
\text { levant ho } \\
\text { nd } \beta_{i}^{2} \text {, th } \\
\text { uation } 4\end{array}$ & tont & . & IIt & IEn, I & 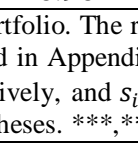 & 150 & , & titest & $111 \mathrm{~s}$ & $\begin{array}{l}\text { ous holdi } \\
\text { ary } 2006 \\
\text { mated in }\end{array}$ & $\begin{array}{l}\text { iods (each } \\
\text { ldition, the } \\
\text { st-ranking }\end{array}$ \\
\hline
\end{tabular}


Table 5 continued.

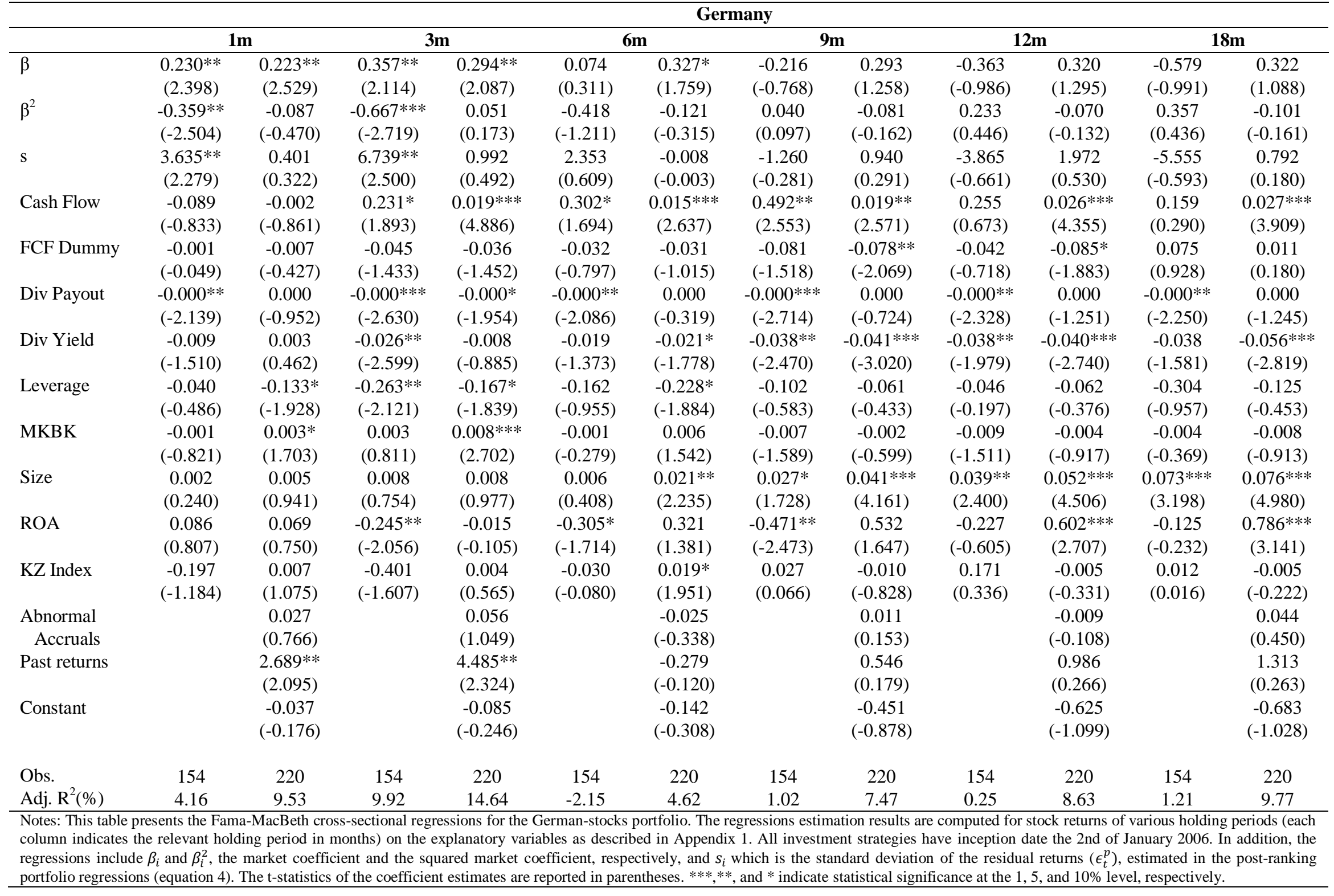


Table 5 continued.

\begin{tabular}{|c|c|c|c|c|c|c|c|c|c|c|c|c|}
\hline \multirow{4}{*}{$\beta$} & \multicolumn{12}{|c|}{ All Countries } \\
\hline & \multicolumn{2}{|c|}{$1 \mathrm{~m}$} & \multicolumn{2}{|c|}{$3 m$} & \multicolumn{2}{|c|}{$6 \mathrm{~m}$} & \multicolumn{2}{|c|}{$9 m$} & \multicolumn{2}{|c|}{$12 \mathrm{~m}$} & \multicolumn{2}{|c|}{$18 \mathrm{~m}$} \\
\hline & 0.510 & -0.086 & 1.520 & -0.100 & 1.509 & -0.204 & 0.607 & -0.122 & -1.004 & -0.203 & -3.100 & -0.070 \\
\hline & (1.140) & $(-0.947)$ & (1.622) & $(-0.691)$ & (1.195) & $(-0.973)$ & $(0.412)$ & $(-0.542)$ & $(-0.537)$ & $(-0.731)$ & $(-1.336)$ & $(-0.172)$ \\
\hline \multirow[t]{2}{*}{$\beta^{2}$} & -0.584 & 0.064 & -1.841 & 0.104 & -1.969 & 0.224 & -0.901 & 0.163 & 1.249 & 0.296 & 3.792 & 0.042 \\
\hline & $(-0.980)$ & $(0.868)$ & $(-1.442)$ & $(0.864)$ & $(-1.151)$ & (1.267) & $(-0.453)$ & $(0.867)$ & $(0.495)$ & (1.279) & $(1.225)$ & (0.119) \\
\hline \multirow[t]{2}{*}{ s } & $3.708 *$ & -0.209 & $8.719 * *$ & 0.764 & 7.329 & 0.978 & 3.790 & $2.532 * *$ & -3.324 & $3.167 * *$ & -10.739 & $3.581^{*}$ \\
\hline & (1.817) & $(-0.397)$ & $(2.290)$ & (0.996) & (1.415) & $(0.862)$ & $(0.617)$ & $(2.033)$ & $(-0.430)$ & (1.969) & $(-1.059)$ & $(1.670)$ \\
\hline \multirow[t]{2}{*}{ Cash Flow } & -0.047 & -0.002 & 0.026 & $0.019 * * *$ & 0.074 & 0.004 & 0.133 & -0.001 & -0.005 & -0.001 & -0.006 & $-0.012 *$ \\
\hline & $(-0.701)$ & $(-1.138)$ & $(0.203)$ & $(6.721)$ & $(0.570)$ & $(0.725)$ & $(0.936)$ & $(-0.262)$ & $(-0.025)$ & $(-0.234)$ & $(-0.018)$ & $(-1.694)$ \\
\hline \multirow[t]{2}{*}{ FCF Dummy } & $-0.020 * *$ & -0.015 & $-0.044 * * *$ & -0.019 & $-0.061 * * *$ & -0.031 & $-0.074 * * *$ & $-0.051 *$ & $-0.059 *$ & -0.040 & -0.050 & -0.017 \\
\hline & $(-2.090)$ & $(-1.416)$ & $(-2.707)$ & $(-1.069)$ & $(-2.899)$ & $(-1.244)$ & $(-3.002)$ & $(-1.921)$ & $(-1.746)$ & $(-1.126)$ & $(-1.112)$ & $(-0.346)$ \\
\hline \multirow[t]{2}{*}{ Div Payout } & $-0.000 * * *$ & $-0.000 * *$ & $-0.000 * * *$ & $-0.000 * * *$ & $-0.000 * * *$ & $-0.000 * * *$ & $-0.000 * * *$ & $-0.000 * * *$ & $-0.000 * * *$ & $-0.000 * * *$ & $-0.000 * * *$ & $-0.001 * * *$ \\
\hline & $(-5.477)$ & $(-2.484)$ & $(-5.760)$ & $(-4.305)$ & $(-3.737)$ & $(-3.334)$ & $(-3.581)$ & $(-3.814)$ & $(-3.810)$ & $(-4.403)$ & $(-2.849)$ & $(-3.843)$ \\
\hline \multirow[t]{2}{*}{ Div Yield } & $-0.008 * * *$ & $-0.013 * * *$ & $-0.016 * * *$ & $-0.028 * * *$ & $-0.016 * *$ & $-0.023 * *$ & $-0.020 * *$ & $-0.037 * * *$ & $-0.035^{* *}$ & $-0.060 * * *$ & $-0.041 *$ & $-0.072 * * *$ \\
\hline & $(-3.493)$ & $(-2.877)$ & $(-2.734)$ & $(-3.929)$ & $(-2.116)$ & $(-2.179)$ & $(-2.300)$ & $(-3.462)$ & $(-2.318)$ & $(-4.165)$ & $(-1.948)$ & $(-3.807)$ \\
\hline \multirow[t]{2}{*}{ Leverage } & -0.010 & -0.009 & $-0.071 *$ & -0.016 & -0.048 & -0.121 & -0.046 & -0.125 & -0.027 & -0.063 & -0.109 & -0.174 \\
\hline & $(-0.419)$ & $(-0.279)$ & $(-1.883)$ & $(-0.333)$ & $(-0.930)$ & $(-1.561)$ & $(-0.876)$ & $(-1.507)$ & $(-0.329)$ & $(-0.566)$ & $(-1.192)$ & $(-1.164)$ \\
\hline \multirow[t]{2}{*}{ MKBK } & $-0.001 * *$ & $0.001 * * *$ & 0.000 & $0.001 * * *$ & -0.001 & $0.001 * * *$ & -0.002 & $0.001 * * *$ & -0.003 & $0.001 * * *$ & -0.003 & $0.001 * * *$ \\
\hline & $(-2.349)$ & $(24.048)$ & $(-0.156)$ & (20.998) & $(-0.583)$ & $(8.956)$ & $(-1.188)$ & (6.456) & $(-1.560)$ & (3.716) & $(-1.313)$ & $(6.213)$ \\
\hline \multirow[t]{2}{*}{ Size } & 0.000 & $0.008 * *$ & -0.001 & $0.015^{* *}$ & 0.004 & 0.011 & $0.016^{* *}$ & $0.023 * *$ & $0.030 * * *$ & $0.025 * *$ & $0.052 * * *$ & $0.042 * *$ \\
\hline & $(-0.011)$ & $(2.176)$ & $(-0.126)$ & (2.129) & $(0.540)$ & (1.278) & $(2.013)$ & $(2.368)$ & $(3.087)$ & $(2.012)$ & $(3.526)$ & $(2.310)$ \\
\hline \multirow[t]{2}{*}{ ROA } & 0.040 & $0.073^{*}$ & -0.049 & -0.046 & -0.087 & -0.082 & -0.133 & -0.091 & 0.008 & -0.247 & 0.018 & $-0.459 *$ \\
\hline & $(0.600)$ & (1.931) & $(-0.385)$ & $(-0.582)$ & $(-0.676)$ & $(-0.407)$ & $(-0.961)$ & $(-0.652)$ & $(0.038)$ & $(-1.596)$ & $(0.058)$ & $(-1.708)$ \\
\hline \multirow[t]{2}{*}{ KZ Index } & -0.273 & -0.001 & $-0.670 *$ & $-0.007 * *$ & -0.636 & -0.007 & -0.378 & -0.009 & 0.240 & -0.015 & 0.882 & -0.011 \\
\hline & $(-1.313)$ & $(-0.482)$ & $(-1.766)$ & $(-2.342)$ & $(-1.256)$ & $(-1.229)$ & $(-0.613)$ & $(-1.521)$ & $(0.318)$ & $(-1.465)$ & (0.922) & $(-0.781)$ \\
\hline \multirow{2}{*}{$\begin{array}{l}\text { Abnormal } \\
\text { Accruals }\end{array}$} & & 0.011 & & 0.014 & & $-0.060 * *$ & & $-0.079 * *$ & & $-0.127 * * *$ & & $-0.112 * *$ \\
\hline & & $(0.931)$ & & $(0.652)$ & & $(-2.055)$ & & $(-2.542)$ & & $(-3.047)$ & & $(-2.072)$ \\
\hline \multirow[t]{2}{*}{ Past returns } & & $0.710 * * *$ & & 0.188 & & -0.242 & & $-2.060 * * *$ & & $-2.277 * * *$ & & $-2.035 * * *$ \\
\hline & & $(5.656)$ & & (0.594) & & $(-0.655)$ & & $(-4.229)$ & & $(-4.915)$ & & $(-2.725)$ \\
\hline \multirow[t]{2}{*}{ Constant } & & -0.007 & & -0.070 & & -0.039 & & -0.266 & & -0.214 & & -0.288 \\
\hline & & $(-0.091)$ & & $(-0.599)$ & & $(-0.225)$ & & $(-1.344)$ & & $(-0.854)$ & & $(-0.874)$ \\
\hline Obs. & 485 & 312 & 485 & 312 & 485 & 312 & 485 & 312 & 485 & 312 & 485 & 312 \\
\hline Adj. $R^{2}(\%)$ & 4.00 & 23.05 & 5.53 & 16.75 & 2.77 & 6.41 & 3.85 & 12.14 & 5.82 & 11.53 & 5.96 & 9.94 \\
\hline Notes: This tab & (io & The & . & cisent & 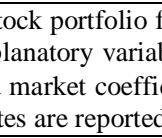 & . & 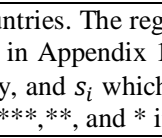 & . & . & 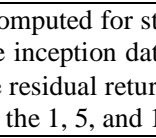 & $\left.\epsilon_{t}^{p}\right)$, & $\begin{array}{l}\text { ous holding } \\
\text { ary } 2006 \text {. In } \\
\text { in the post- } \\
\text { vely. }\end{array}$ \\
\hline
\end{tabular}


Appendix 1 - Definition of independent variables used in the logistic regression models

Variable

Cash Flow

FCF Dummy

Dividend Payout

Dividend Yield

Leverage

MKBK

SIZE

ROA

KZ-index

Abnormal accruals

Prior returns
It is the ratio of net operating income before taxes and depreciation to total assets.

A binary variable that takes the value of one for firms that have simultaneously low Tobin's $q$ (lower than the median $q$ of a firm's respective industry for each respective year) and high cash flow (higher than the median cash flow of the respective industry for each year) and the value of zero otherwise

It is the ratio of total cash dividends relative to net income.

Is the ratio of total cash dividends relative to the year-end share price.

It is the ratio of total debt to total assets.

It is the ratio of market value relative to the book value of equity.

It is the natural logarithm of total assets.

It is the ratio of net income to total assets.

It is the Kaplan and Zingales (1997) index of financial constraint, as estimated in Chen and Wang (2012). In particular, the KZ-index is estimated as KZ=-1.002(Cash Flow over Total Assets - lagged) 39.368(Total Cash Dividends over Total Assets - lagged) - 1.315(Cash Balances over Total Assets - lagged) + 3.139(Total Debt over Total Assets - lagged) +0.283 (Market-to-Book value). In addition, the components of the KZ-index are winsorized at the $1^{\text {st }}$ and $99^{\text {th }}$ percentile.

Abnormal accruals are estimated as in Gong et al. (2008). In particular, abnormal accruals are the residuals of regressing Total Accruals against the change in Sales, Property Plant and Equipment, and Total Assets; while Total Accruals (TA) are estimated as TA=Change in Current Assets - Change in Current Liabilities - Change in Cash + Change in Debt included in current Liabilities - Depreciation and Amortization Expense.

It is estimated as the 6-month (days -151 to 2 days) market-adjusted stock returns. 


\section{References}

Alzahrani, M. and Lasfer, M., 2012. Investor protection, taxes and dividends. Journal of Corporate Finance 18, 745-762.

Andriosopoulos, D., C. Gaganis, F. Pasiouras, and C. Zopounidis, 2012, “An application of multicriteria decision aid models in the prediction of open market share repurchases," Omega 40, 882-890.

Andriosopoulos, D. and Lasfer, M., 2014. The market valuation of share repurchases in Europe. Journal of Banking and Finance, forthcoming.

Andriosopoulos, D., Hoque, H., 2013. The determinants of share repurchases in Europe. International Review of Financial Analysis 27, 65-76.

Bagwell, L.S. and Shoven, J.B., 1988. Share repurchases and acquisitions: An analysis of which firms participate. In Auerbach, A. (Ed.), Corporate Takeovers: Causes and Consequences, University of Chicago Press 191-220.

Bagwell, L.S. and Shoven, J.B., 1989. Cash Distributions to Shareholders, Journal of Economic Perspective 3, 129-140.

Baker, H.K., Powell, G.E., Veit, T.E., 2003. Why companies use open-market repurchases: A managerial perspective. Quarterly Review of Economics and Finance 43, 483-504.

Barber, B.M. and Lyon, J.D., 1997. Detecting long-run abnormal stock returns: The empirical power and specification of test statistics. Journal of Financial Economics 43, 341-372.

Barber, B.M., Lyon, J.D., Tsai, C.L., 1999. Improved Methods for Tests of Long-Run Abnormal Stock Returns. Journal of Finance 54, 165-201.

Barth, M.E. and Kasznik R., 1999. Share repurchases and intangible assets, Journal of Accounting and Economics 28, 211-241. 
Bartram, S.M., Brown, P.R., How, J.C.Y., Verhoeven, P., 2009. Agency Conflicts and Corporate Payout Policies: A Global Study. Available at SSRN: http://ssrn.com/abstract=1068281.

Bhattacharya, U. and Dittmar, A., 2003. Costless versus costly signaling: Theory and evidence from share repurchasing. Available at SSRN: http://ssrn.com/abstract=250049.

Brounen, D., De Jong, A., and Koedjik, K., 2004. Corporate finance in Europe: Confronting theory with practice, Financial Management 33, 61-101.

Chan, K., Ikenberry, D., Lee, I., 2004. Economic sources of gain in stock repurchases. Journal of Financial and Quantitative Analysis 39, 461-479.

Chan, K., Ikenberry, D., Lee, I., 2007. Do managers time the market? Evidence from openmarket share repurchases. Journal of Banking and Finance 31, 2673-2694.

Chen, S.S., and Wang, Y., 2012. Financial constraints and share repurchases. Journal of Financial Economics 105, 311-331.

Comment, R. and Jarrell, G.A., 1991. The relative signaling power of Dutch-auction and fixedprice self-tender offers and open-market share repurchases, Journal of Finance 46, 12431271.

Dittmar, A.K., 2000. Why do firms repurchase stock? Journal of Business 73, 331-355.

Fama, E., MacBeth, J., 1973. Risk, return, and equilibrium: empirical tests. Journal of Political Economy 81, 607-636.

Gong, G., Louis, H., Sun, A.X., 2008. Earnings management and firm performance following open-market repurchases. Journal of Finance 63, 947-986.

Grullon, G. and Michaely, R., 2002. Dividends, share repurchases, and the substitution hypothesis, Journal of Finance 57, 1649-1684.

Grullon, G. and Michaely, R., 2004. The information content of share repurchase programs. Journal of Finance 59, 651-680. 
Hovakimian, A., Opler, T. and Titman, S., 2001. The debt-equity choice, Journal of Financial and Quantitative Analysis 36, 1-24.

Ikenberry, D., Lakonishok, J., and Vermaelen, T., 1995. Market underreaction to open market share repurchases, Journal of Financial Economics 39, 181-208.

Ikenberry, D., Lakonishok, J., and Vermaelen, T., 2000. Stock repurchases in Canada: Performance and strategic trading, Journal of Finance 55, 2373-2397.

Ikenberry, D., Vermaelen, T., 1996. The option to repurchase stock. Financial Management 25, 9-24.

Jagannathan, M., Stephens, C., 2003. Motives for multiple open-market repurchase programs. Journal of the Financial Management Association 32, 71-91.

Kaplan, S., and Zingales,L.,1997. Do investment-cash flow sensitivities provide useful measures of financing constraints? Quarterly Journal of Economics 112,169-215.

Katz, S., Lilien, S., and Nelson, B., 1985. Stock market behavior around bankruptcy model distress and recovery predictions. Financial Analysts Journal, 41(1), 70-73

Kothari, S.P., and Warner, J.B. 1997. Measuring long-horizon security performance. Journal of Financial Economics 43, 301-39

La Porta, R., Lopez-de-Silanes, F., and Shleifer, A., 1999. Corporate ownership around the world, Journal of Finance 54, 471-517.

La Porta, R., Lopez-de-Silanes, F., Shleifer, A., and Vishny, R., 1997. Legal determinants of external finance, Journal of Finance 52, 1131-1150.

La Porta, R., Lopez-de-Silanes, F., Shleifer, A., and Vishny, R., 1998. Law and finance, Journal of Political Economy 106, 1113-1155.

La Porta, R., Lopez-de-Silanes, F., Shleifer, A., and Vishny, R., 2000. Agency problems and dividend policies around the world, Journal of Finance 55, 1-33. 
La Porta, R., Lopez-de-Silanes, F., Shleifer, A., and Vishny, R., 2002. Investor Protection and Corporate Valuation, Journal of Finance 57, 1147-1170.

Lakonishok, J. and Vermaelen T., 1990. Anomalous Price Behavior Around Repurchase Tender Offers. Journal of Finance 45, 455-477.

Lasfer, M.A., 2005. The market valuation of share repurchases in Europe, unpublished working paper, Cass Business School, London.

Manconi, A., Peyer, U., Vermaelen, T., 2013. Buyback around the world. Insead Working paper 2013/101/FN.

Masulis, RW., 1980. Stock repurchase by tender offer: An analysis of the causes of common stock price changes. Journal of Finance 35, 305-319.

McNally, W.J. and Smith, B.F., 2007. Long-run returns following open market share repurchases. Journal of Banking and Finance 31, 703-717.

McNally, W.J., 1999. Open market stock repurchase signaling, Financial Management 28, 5567.

Mitchell, J.D. and Dharmawan, G.V., 2007. Incentives for on-market buy-backs: Evidence from a transparent buy-back regime, Journal of Corporate Finance 13, 146-169.

Morck, R., Wolfenzon, D. and Yeung, B., 2005. Corporate governance, economic entrenchment and growth, Journal of Economic Literature 43, 655-720.

Newey, W., West, K., 1987. A simple, positive semi-definite, heteroskedasticity and autocorrelation consistent covariance matrix. Econometrica 55, 703-708.

Opler, T. and Titman S., 1993. The determinants of leveraged buyout activity: Free cash flow vs. financial distress, Journal of Finance 48, 1985-1999.

Oswald, D. and Young, S, 2004. What role taxes and regulation? A second look at open market share buyback activity in the UK, Journal of Business Finance and Accounting 31, 257292. 
Ouzounis G., Gaganis Ch., Zopounidis C. 2009. Prediction of Acquisitions and Portfolio Returns. International Journal of Banking, Accounting and Finance 1, 381-406.

Peyer, U., and T. Vermaelen, 2009, "The Nature and Persistence of Buyback Anomalies," Review of Financial Studies 22, 1693-1745.

Peyer, U.C. and Vermaelen, T., 2005. The many facets of privately negotiated stock repurchases, Journal of Financial Economics 75, 361-395

Peyer, U.C. and Vermaelen, T., 2009. The Nature and Persistence of Buyback Anomalies, Review of Financial Studies 22, 1693-1745.

Powell, R.G. 2001. Takeover prediction and portfolio performance: A note. Journal of Business Finance \& Accounting 28, 993-1011.

Powell, R.G. 2004. Takeover prediction models: A multinomial approach. Multinational Finance Journal 8, 35-74.

Rau, P.R. and Vermaelen, T., 2002. Regulation, taxes, and share repurchases in the U.K., Journal of Business 75, 245-282.

Stephens, C.P. and Weisbach, M.S., 1998. Actual share reacquisitions in open-market repurchase programs, Journal of Finance 53, 313-333.

v.Eije, H. and Megginson, W.L. 2008. Dividends and share repurchases in the European Union, Journal of Financial Economics 89, 347-374.

Vermaelen, T., 1981. Common stock repurchases and market signaling, Journal of Financial Economics 9, 139-183. 